\title{
Comprehensive Survey of Multi-Elements in Coastal Sea and Stream Sediments in the Island Arc Region of Japan: Mass Transfer from Terrestrial to Marine Environments
}

\author{
Atsuyuki Ohta and Noboru Imai \\ Geological Survey of chpan, AIST
}

clopan

\section{Introduction}

The dispersion of sediments across terrestrial areas, estuaries, shelves, slopes, and basins in island arc regions is extremely active. Because Japan is surrounded by vast oceans, it is fundamentally important to know sediment characteristics and dispersal systems upon the shelf and slope in terms of the erosion, transport, and deposition of sediments. Coastal seas, especially inner bays, often sustain severe damage from anthropogenic activities. Geochemical characteristics of marine sediments provide valuable clues regarding the dispersion of sediments. So far, the diffusion and fixation process of elements in the vertical direction and the past sedimentary environment found in core samples have attracted considerable scientific interest. However, regional spatial distributions of the chemical compositions of sediments in land, estuaries, and coastal areas are less understood (e.g., Balls et al., 1997; Degens et al., 1991; Ibbeken \& Schleyer, 1991; Irion et al., 1995; Karageorgis et al., 2005; Voutsinou-Taliadouri \& Varnavas, 1995; Wang et al., 2008).

To better understand the spatial distribution of the elements in the earth's surface, a geochemical map is used. The purpose of the map is to obtain natural geochemical baselines on the earth's surface because the geochemical history of the earth's surface is a fundamental part of geo-information. Many countries have produced national geochemical atlases to explore mineral recourses and address growing concerns about environmental problems (Fauth et al., 1985; Gustavsson et al., 2001; Lis \& Pasieczna, 1995; Shacklette \& Boerngen, 1984; Thalmann et al., 1988; Weaver et al., 1983; Webb et al., 1978; Xie et al., 1997; Zheng, 1994). Simultaneously, cross-boundary and sub-continental geochemical mapping projects have actively been carried out (e.g., Bølviken et al., 1986; Reimann et al., 1998; Salminen et al., 2005). Furthermore, the International Geochemical Mapping Project (IGCP 259) was initiated in 1988 under the auspices of the UNESCO to compile data on the global geochemical composition of the earth's surface (Darnley et al., 1995).

Thus, geochemical mapping has been undertaken globally, but it is restricted to terrestrial areas because surveys of soils, stream sediments, and river water samples are easy. However, $70 \%$ of the earth's surface is covered by water. Surveying marine sediments is important to elucidate the mass transfer from land to sea. The Geological Survey of Japan, National Institute of Advanced Industrial Science and Technology, has conducted research on the fundamental 
geochemical properties of earth surface materials (Imai et al., 2004, 2010). For a geochemical mapping project, 3,024 river sediments and 4,905 surface marine sediments around Japan were collected and were subsequently analyzed for 53 elements including toxic elements (e.g., As, $\mathrm{Cd}$, and $\mathrm{Hg}$ ). We have taken the initiative in determining the regional elemental distribution for both the land and sea. We intend to elucidate the geochemical differences of terrestrial surface sediments and coastal and open sea sediments comprehensively.

Geochemical variation occurring among terrestrial areas has been explained conclusively in relation to the lithology and distribution of mineral deposits. Japanese geology has particularly complicated distributions, and many mineral deposits occur on a smaller scale than those of Europe, the United States, or China, which are situated on older continental terrains. Basically, regional geochemical maps are intended to be utilized for environmental assessments. To achieve a more objective and quantitative interpretation of geochemical maps, we carried out a watershed hydrological estimation of geology using the Geographic Information System and statistical methods such as the analysis of variance and multiple comparison tests to analyze geochemical datasets (Ohta et al., 2004a, 2004b, 2005a, 2005b).

In contrast, large geochemical mapping datasets in the ocean present difficulties in determining the dominant geochemical factors controlling geochemical distributions in coastal areas (Imai et al., 1997; Ohta et al., 2004b, 2007, 2010). This is because of the following effects: (1) mass transport from the land to coastal seas, (2) particle size effects, (3) transportation of coastal sediments by a gravity flow or by an oceanic current, (4) mixing of volcanic materials such as tephra and pumice, (5) early diagenetic processes, (6) denudation or resedimentation of basement rocks, (7) biogenic products such as shell fragments, foraminifera tests, and fecal pellets, and (8) contamination caused by human activity. In this paper, we introduce comprehensive land-marine geochemical maps that can be used by persons unfamiliar with geochemical maps. Furthermore, we discuss the mass transfer process on the earth's surface using these geochemical maps.

\section{Study area}

\subsection{Terrestrial areas}

Japan consists of over 6,800 islands of various sizes. In this study, we focus on four major islands: the Hokkaido, Honshu, Shikoku, and Kyushu Islands. Japanese geography is characterized by variable topography (Fig. 1a). The central region contains the high mountains. From this region, the elevation decreases steeply from 1,000-3,000 $\mathrm{m}$ to sea level within a distance of only $20-30 \mathrm{~km}$. The main streams flowing from these mountains formed large coastal plains during the Pliocene-Pleistocene. Rice fields, residential areas, and industrial areas extend throughout these flood plains.

Figure $1 \mathrm{~b}$ shows a geological map of the studied area, simplified from the Geological Map of Japan (scale: 1:1,000,000) (Geological Survey of Japan, 1992). Japan originated at the east end of the Eurasian plate and formed as an island arc during the Neogene period. The geology of Japan is quite different from that of Europe, America, and China, which are old continental terrains. Around $40 \%$ of Japan is covered by poorly lithified sediments formed in the Quaternary-Neogene age and sedimentary rocks deposited before the Paleogene era. Accretionary complexes (accretionary prisms or accretionary wedge) consist mainly of melange, mudstone, and sandstone and are associated with small amounts of chert, limestone, greenstone, gabbro, and ultramafic rocks. They are subducted sediments and were formed by scraped trench-fill deposits and pelagic sediments on the oceanic plate during the subduction 
process. The sedimentary rocks and igneous rocks of accretionary complexes reside in $15 \%$ and $2 \%$ of the area, respectively.

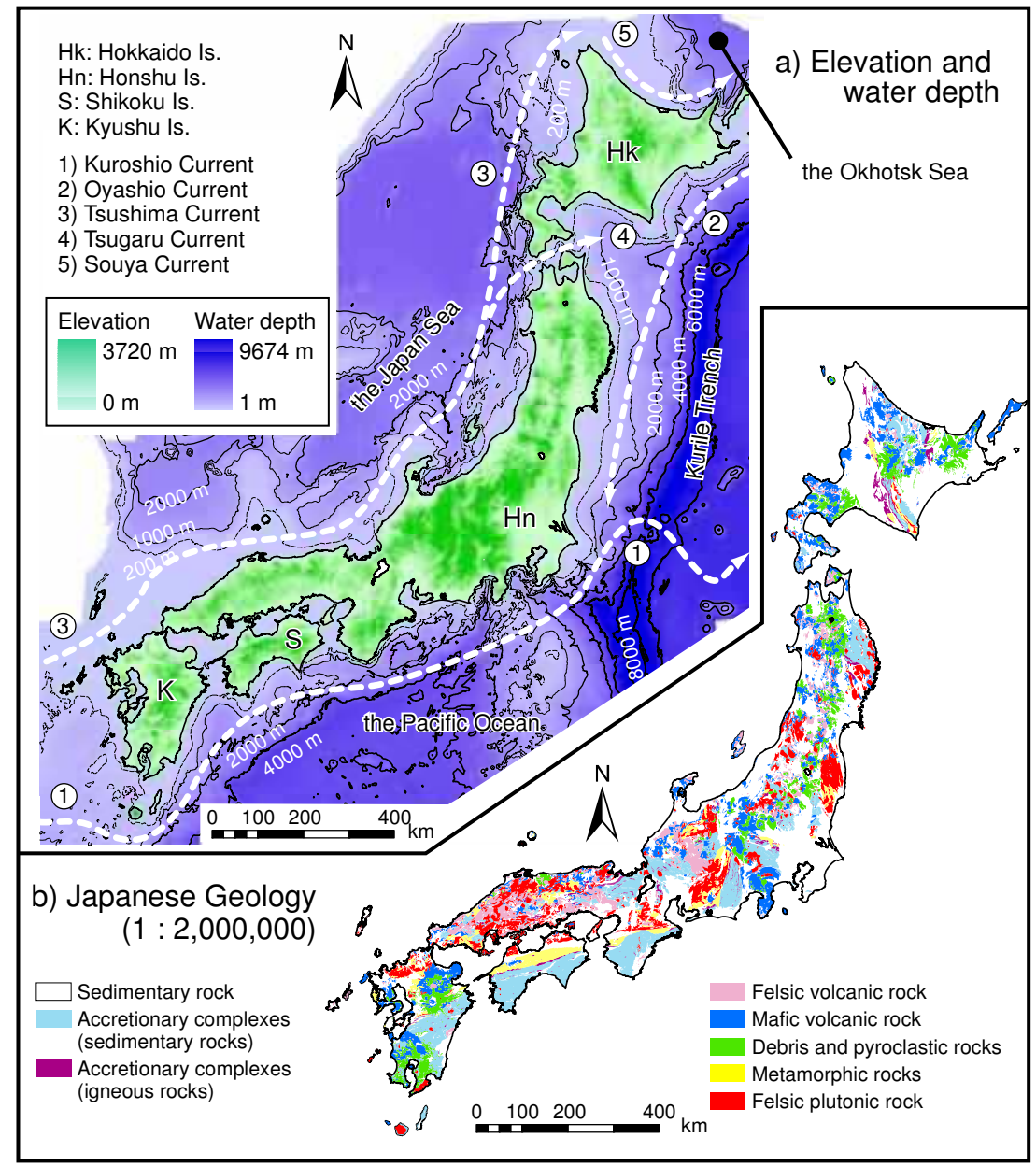

Fig. 1. a) Japanese topography and bathymetric features. b) Japanese geological map Japan is a very active volcanic island. Non-alkaline volcanic rocks (mainly dacitic-andesitic lava, tuff, and pyroclastic flow materials) were formed in the Neogene-Quaternary and crop out in $23 \%$ of the area. Granitic rocks mostly intruded during the Cretaceous age and compose $10 \%$ of the area. Metamorphic rocks are scarce in the area (less than $4 \%$ ). Many mineral deposits of hydrothermal vein-, skarn-, Kuroko-, and Kieslager-type bearing Au, $\mathrm{Ag}, \mathrm{As}, \mathrm{Cu}, \mathrm{Zn}, \mathrm{Cd}, \mathrm{Sb}, \mathrm{Hg}$, and $\mathrm{Pb}$ are distributed in Japan.

\subsection{Coastal sea area}

Japan is surrounded by three oceans: the Pacific Ocean, the Japan Sea, and the Okhotsk Sea (Fig. 1a). Japan has a narrow continental shelf except in the west and north. In the Pacific 
Ocean, the marine environment has a steep slope from the coast: the water depth reaches $1,000 \mathrm{~m}$ just $20-40 \mathrm{~km}$ offshore. The Kuril Trench is a deep valley where the Pacific Plate is subducting and the water depth is greater than 7,000 m. The west part of the Pacific Ocean has some deep valleys where the Philippine Plate is subducting and the water depth is greater than 2,000 m. Gravity flow deposits are found extensively on the slope and in these submarine canyons. The Oyashio Current flows in the counter clockwise direction and the Kuroshio Current flows in the SW-NE direction. The Japan Sea has an average depth of $1,750 \mathrm{~m}$. The wide continental shelf spread is in the western and northern part of the Japan Sea. The Tsushima Current, the branch current of the Kuroshio Current, flows from SW to NE. The current conveys a warm water mass to the surface of the sea. In the deep regions of the sea, cold and oxygen-rich water exists, which is formed in the winter season. The wide continental shelf is also present in the Okhotsk Sea. The Soya Current, a branch current of the Tsushima Current, flows on the shelf in the counter clockwise direction. Drift ice covers the area from February to April, thereby transporting allochthonous debris. Taken as a whole, coarse and fine sands are distributed on the shelf. Very fine sand, silt, and clay are distributed on inner bays, slopes, and basins. Coarse sediments distributing in the shelf generally contain a large amount of shell fragments.

\section{Materials and methods}

The 3,024 stream sediments used for the combined geochemical mapping were collected from adjacent terrestrial regions covering an area of 378,000 km² during 1999-2003 (Fig. 2). The sampling density is one sample per $80-120 \mathrm{~km}^{2}$ (Imai et al., 2004). The stream sediments were dried in air and sieved with an 83-mesh $(180 \mu \mathrm{m})$ screen. Magnetic minerals were removed using a magnet, thereby minimizing the effect of the accumulation of magnetic minerals. The samples were not milled. Sieving might change elemental concentrations from the bulk stream sediments. However, Imai (1987) suggested that sieving with an 83-mesh $(180 \mu \mathrm{m})$ screen hardly changes elemental concentrations from bulk stream sediments, although enrichment of $\mathrm{Cu}, \mathrm{Ni}, \mathrm{Zn}$, and $\mathrm{Pb}$ appears in the finer fractions passing through a 390-mesh $(38 \mu \mathrm{m})$ screen.

In all, 4,905 marine sediments were collected using a grab sampler in 1980-2007 (Fig. 2). These samples represent an area of c.a. $460,000 \mathrm{~km}^{2}$. The mean sampling density of the coastal sea sediments is one sample per $90 \mathrm{~km}^{2}$. The uppermost area of $0-3 \mathrm{~cm}$ of the sediments collected with the grab sampler was separated, dried in air, ground with an agate mortar and pestle, and retained for chemical analyses. Rocky, cobble, pebble, and gravel sediments were not used for geochemical mapping. Alternatively, matrix sediments were collected from these samples.

First, $0.2 \mathrm{~g}$ of each sample was digested using $5 \mathrm{~mL} \mathrm{HF}, 4 \mathrm{~mL} \mathrm{HNO}_{3}$, and $3 \mathrm{~mL} \mathrm{HClO}_{4}$ solutions at $120^{\circ} \mathrm{C}$ for $2 \mathrm{~h}$ (Imai, 1990). The degraded product was evaporated to dryness under $200^{\circ} \mathrm{C}$, and the residue was dissolved with $100 \mathrm{~mL}$ of $0.35 \mathrm{M} \mathrm{HNO}_{3}$ solution. The concentrations of the 51 elements were determined using ICP-AES (for $\mathrm{Na}, \mathrm{Mg}, \mathrm{Al}, \mathrm{P}, \mathrm{K}, \mathrm{Ca}$, $\mathrm{Ti}, \mathrm{Mn}, \mathrm{Fe}, \mathrm{V}, \mathrm{Sr}$, and $\mathrm{Ba}$ ) and ICP-MS (for $\mathrm{Li}, \mathrm{Be}, \mathrm{Sc}, \mathrm{Cr}, \mathrm{Co}, \mathrm{Ni}, \mathrm{Cu}, \mathrm{Zn}, \mathrm{Ga}, \mathrm{Rb}, \mathrm{Zr}, \mathrm{Nb}, \mathrm{Y}$, Mo, Cd, Sn, Sb, Cs, La, Ce, Pr, Nd, Sm, Eu, Gd, Tb, Dy, Ho, Er, Tm, Yb, Lu, Hf, Ta, Tl, Pb, Bi, $\mathrm{Th}$, and $\mathrm{U}$ ). The As and $\mathrm{Hg}$ analyses were subcontracted to ALS Chemex (Vancouver, BC). The geochemical reference samples JB-1 and JB-3 (Imai et al., 1995) were inserted the rate of 10 and 20 samples, respectively, for quality control. The methodology was examined by Imai (1990) and Ujiie-Mikoshiba et al. (2006). They concluded that the precision and accuracy 


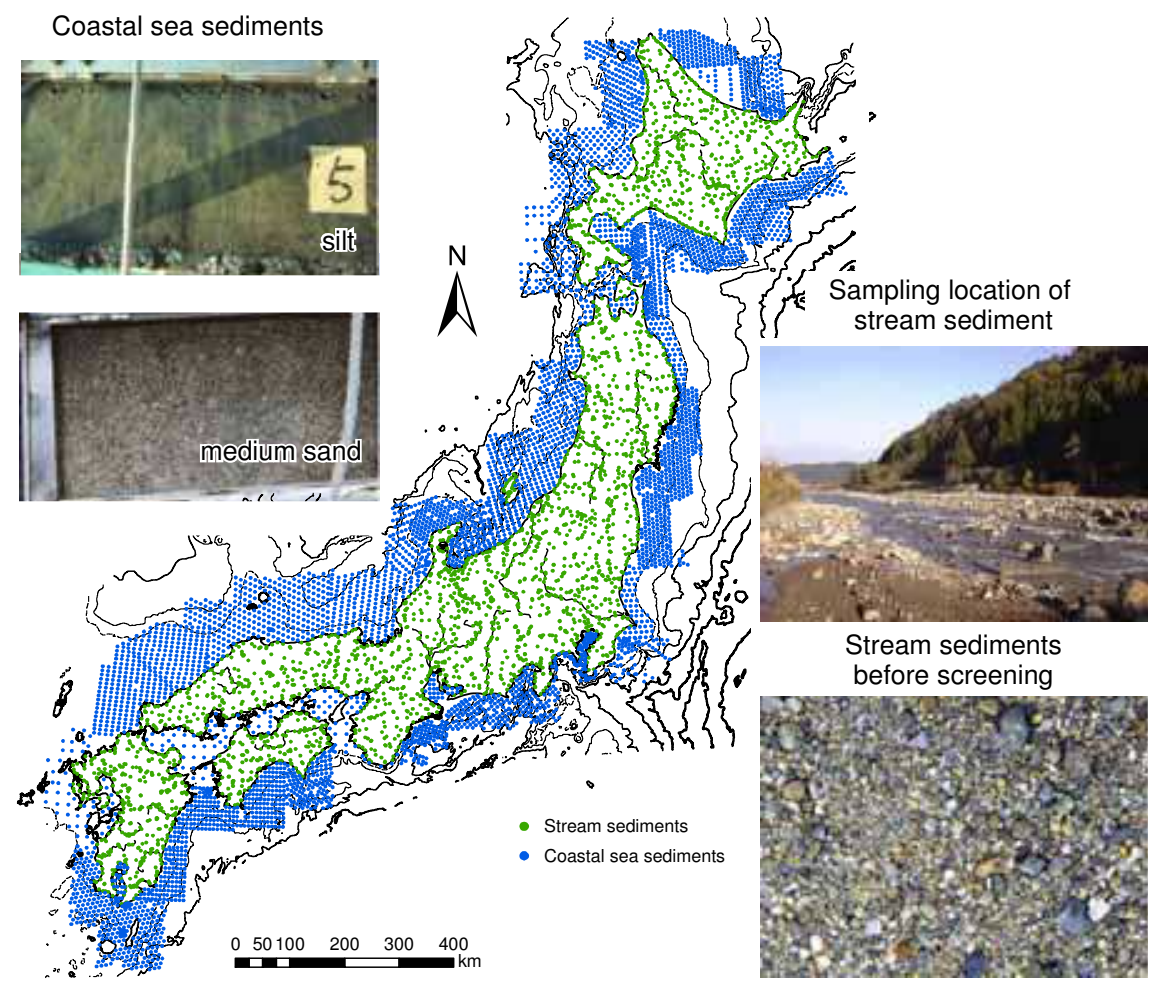

Fig. 2. Sampling locations. Bathymetric features are the same as Fig. 1

of the analytical data were satisfactory, although the method gave higher concentrations of $\mathrm{Mg}$ and lower concentrations of $\mathrm{Al}$ and heavy rare earth elements for some samples. A part of the heavy mineral fraction, especially zircon, is not digested satisfactorily by $\mathrm{HF}, \mathrm{HNO}_{3}$, and $\mathrm{HClO}_{4}$. Incomplete decomposition of these minerals seriously affects a few elements, such as $\mathrm{Zr}$ and Hf (Imai, 1987, 1990). Therefore, the data regarding $\mathrm{Zr}$ and Hf in the sediments should be used only as a guide. In addition, the marine sediments were not desalinated. The Na concentrations in marine sediments are also used as a guide. Table 1 presents the median value of the analytical results obtained for the coastal sea and river sediments. Major elements $(\mathrm{Na}, \mathrm{Mg}, \mathrm{Al}, \mathrm{P}, \mathrm{K}, \mathrm{Ca}, \mathrm{Ti}, \mathrm{Mn}$, and $\mathrm{Fe}$ ) in the sediments are expressed as oxides because they are most abundant in the Earth's crust and their abundance is frequently expressed in terms of weight percent oxide. Although $\mathrm{Mn}$ and $\mathrm{Fe}$ exhibit three and two valences in the environment, respectively, their oxides are expressed as $\mathrm{MnO}$ and $\mathrm{Fe}_{2} \mathrm{O}_{3}$ in this paper.

\section{Geochemical map preparation}

Geographic Information System software (ArcGIS 9.3; Environmental Systems Research Institute, ESRI) was used to prepare geochemical maps. Geochemical maps were created as mesh maps. The elemental concentration of each cell was an interpolation of scatter points based on the inverse distance weighted method (Watson and Philip, 1985). This method 


\begin{tabular}{|c|c|c|c|c|c|c|c|}
\hline Elements & Units & $\begin{array}{c}\text { River } \\
\text { Sed. }\end{array}$ & $\begin{array}{c}\text { Marine } \\
\text { Sed. }\end{array}$ & Elements & Units & $\begin{array}{c}\text { River } \\
\text { Sed. }\end{array}$ & $\begin{array}{c}\text { Marine } \\
\text { Sed. }\end{array}$ \\
\hline $\mathrm{Li}$ & $\mathrm{mg} / \mathrm{kg}$ & 28 & 31 & $\mathrm{Sn}$ & $\mathrm{mg} / \mathrm{kg}$ & 2.1 & 1.5 \\
\hline $\mathrm{Be}$ & $\mathrm{mg} / \mathrm{kg}$ & 1.32 & 1.17 & $\mathrm{Sb}$ & $\mathrm{mg} / \mathrm{kg}$ & 0.60 & 0.52 \\
\hline $\mathrm{Na}_{2} \mathrm{O}$ & wt. \% & 2.16 & 3.08 & $\mathrm{Cs}$ & $\mathrm{mg} / \mathrm{kg}$ & 3.6 & 3.0 \\
\hline $\mathrm{MgO}$ & wt. \% & 2.56 & 2.81 & $\mathrm{Ba}$ & $\mathrm{mg} / \mathrm{kg}$ & 410 & 320 \\
\hline $\mathrm{Al}_{2} \mathrm{O}_{3}$ & wt. \% & 10.87 & 9.07 & $\mathrm{La}$ & $\mathrm{mg} / \mathrm{kg}$ & 16 & 13 \\
\hline $\mathrm{P}_{2} \mathrm{O}_{5}$ & wt. \% & 0.12 & 0.12 & $\mathrm{Ce}$ & $\mathrm{mg} / \mathrm{kg}$ & 30 & 26 \\
\hline $\mathrm{K}_{2} \mathrm{O}$ & wt. \% & 1.74 & 1.71 & $\mathrm{Pr}$ & $\mathrm{mg} / \mathrm{kg}$ & 3.9 & 3.2 \\
\hline $\mathrm{CaO}$ & wt. \% & 2.34 & 4.01 & $\mathrm{Nd}$ & $\mathrm{mg} / \mathrm{kg}$ & 16 & 13 \\
\hline $\mathrm{Sc}$ & $\mathrm{mg} / \mathrm{kg}$ & 13 & 10 & $\mathrm{Sm}$ & $\mathrm{mg} / \mathrm{kg}$ & 3.3 & 2.7 \\
\hline $\mathrm{TiO}{ }_{2}$ & wt. \% & 0.72 & 0.46 & $\mathrm{Eu}$ & $\mathrm{mg} / \mathrm{kg}$ & 0.82 & 0.68 \\
\hline $\mathrm{V}$ & $\mathrm{mg} / \mathrm{kg}$ & 120 & 86 & $\mathrm{Gd}$ & $\mathrm{mg} / \mathrm{kg}$ & 3.1 & 2.5 \\
\hline $\mathrm{Cr}$ & $\mathrm{mg} / \mathrm{kg}$ & 53 & 47 & $\mathrm{~Tb}$ & $\mathrm{mg} / \mathrm{kg}$ & 0.55 & 0.44 \\
\hline $\mathrm{MnO}$ & $\mathrm{wt.} \%$ & 0.12 & 0.06 & $\mathrm{Dy}$ & $\mathrm{mg} / \mathrm{kg}$ & 2.9 & 2.2 \\
\hline $\mathrm{Fe} \mathrm{O}_{3}$ & $\mathrm{wt.} \%$ & 5.74 & 4.34 & $\mathrm{Ho}$ & $\mathrm{mg} / \mathrm{kg}$ & 0.56 & 0.43 \\
\hline $\mathrm{Co}$ & $\mathrm{mg} / \mathrm{kg}$ & 14 & 9 & $\mathrm{Er}$ & $\mathrm{mg} / \mathrm{kg}$ & 1.7 & 1.3 \\
\hline $\mathrm{Ni}$ & $\mathrm{mg} / \mathrm{kg}$ & 21 & 20 & $\mathrm{Tm}$ & $\mathrm{mg} / \mathrm{kg}$ & 0.27 & 0.20 \\
\hline $\mathrm{Cu}$ & $\mathrm{mg} / \mathrm{kg}$ & 27 & 16 & $\mathrm{Yb}$ & $\mathrm{mg} / \mathrm{kg}$ & 1.7 & 1.2 \\
\hline $\mathrm{Zn}$ & $\mathrm{mg} / \mathrm{kg}$ & 107 & 75 & $\mathrm{Lu}$ & $\mathrm{mg} / \mathrm{kg}$ & 0.25 & 0.18 \\
\hline $\mathrm{Ga}$ & $\mathrm{mg} / \mathrm{kg}$ & 16 & 13 & $\mathrm{Hf}$ & $\mathrm{mg} / \mathrm{kg}$ & 1.5 & 1.3 \\
\hline $\mathrm{As}$ & $\mathrm{mg} / \mathrm{kg}$ & 8 & 7 & $\mathrm{Ta}$ & $\mathrm{mg} / \mathrm{kg}$ & 0.57 & 0.46 \\
\hline $\mathrm{Rb}$ & $\mathrm{mg} / \mathrm{kg}$ & 66 & 54 & $\mathrm{Hg}$ & $\mathrm{mg} / \mathrm{kg}$ & 0.04 & 0.05 \\
\hline $\mathrm{Sr}$ & $\mathrm{mg} / \mathrm{kg}$ & 150 & 220 & $\mathrm{Tl}$ & $\mathrm{mg} / \mathrm{kg}$ & 0.47 & 0.40 \\
\hline $\mathrm{Y}$ & $\mathrm{mg} / \mathrm{kg}$ & 17 & 13 & $\mathrm{~Pb}$ & $\mathrm{mg} / \mathrm{kg}$ & 21 & 19 \\
\hline $\mathrm{Zr}$ & $\mathrm{mg} / \mathrm{kg}$ & 54 & 47 & $\mathrm{Bi}$ & $\mathrm{mg} / \mathrm{kg}$ & 0.23 & 0.25 \\
\hline $\mathrm{Nb}$ & $\mathrm{mg} / \mathrm{kg}$ & 7.2 & 5.3 & $\mathrm{Th}$ & $\mathrm{mg} / \mathrm{kg}$ & 5.4 & 4.2 \\
\hline $\mathrm{Mo}$ & $\mathrm{mg} / \mathrm{kg}$ & 1.2 & 0.9 & $\mathrm{U}$ & $\mathrm{mg} / \mathrm{kg}$ & 1.3 & 1.1 \\
\hline $\mathrm{Cd}$ & $\mathrm{mg} / \mathrm{kg}$ & 0.13 & 0.08 & & & & \\
\hline
\end{tabular}

Table 1. Median values of 53 elemental concentrations of river $(\mathrm{N}=3,024)$ and coastal sea sediments $(\mathrm{N}=4,905)$ in Japan

assumes that interpolating surface data is influenced predominately by the nearby points and less by distant points. In this study, the concentration data for a $2 \mathrm{~km} \times 2 \mathrm{~km}$ cell was calculated from the nearest 12 points. A power value of 2 was chosen to decrease the weight of distant values. The stream sediment is considered to consist of soil and rocks in the catchment area upstream from the sampling site (Howarth and Thornton, 1983). A sampling site is presumed to express the average chemical concentrations in a drainage basin. Therefore, several additional data points were generated within each river basin in addition to the original survey points $(3,024$ points); that is, the catchment area was expressed by a set of points. This method facilitates the creation of mesh maps considering the watershed and the exploration of the data (Ohta et al., 2004b). In contrast, the marine geochemical maps were simply interpolated as a mesh map with a $2 \mathrm{~km} \times 2 \mathrm{~km}$ cell, because it was not necessary to consider the watershed. The resultant marine geochemical maps were combined with the existing land geochemical maps, which were depicted by considering the watershed. 

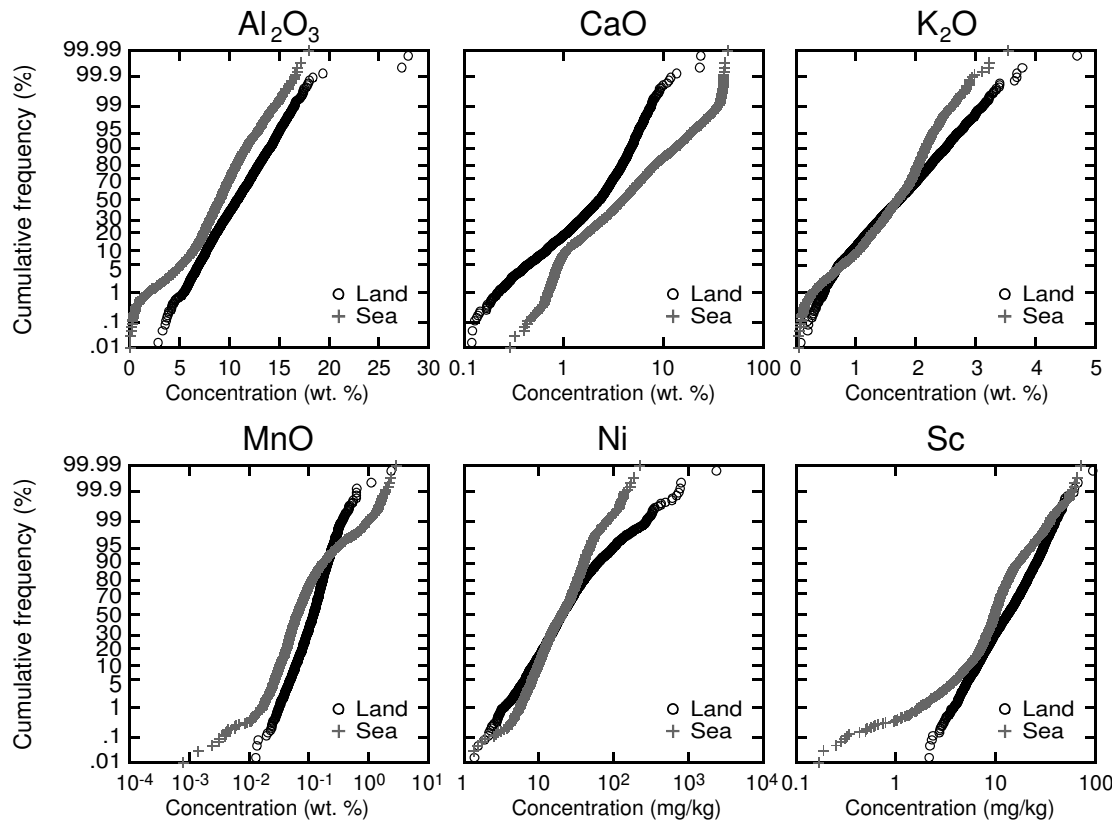

Fig. 3. The cumulative probability plots of six elements

A geochemical map is expressed as a color map, where each cell is color-coded according to a particular classification. In this paper, we applied percentiles $(0 \leq x \leq 5,5<x \leq 10,10<x \leq$ $25,25<x \leq 50,50<x \leq 75,75<x \leq 90,90<x \leq 95$, and $95<x \leq 100 \%$, where $x$ represents the elemental concentration) as a classification according to Reimann (2005). Furthermore, the classification of elemental concentrations was calculated separately in terrestrial and coastal areas because marine sediments and stream sediments differ in their chemical and mineralogical compositions, particle size, and origin (Ohta et al., 2004b, 2007, 2010). Figure 3 portrays the cumulative probability plots of six elements. The $\mathrm{Al}\left(\mathrm{Al}_{2} \mathrm{O}_{3}\right)$ contents in land are systematically higher than those in the coastal sea; the $\mathrm{Ca}(\mathrm{CaO})$ contents are in stark contrast to $\mathrm{Al}\left(\mathrm{Al}_{2} \mathrm{O}_{3}\right)$. The ranges of $\mathrm{K}\left(\mathrm{K}_{2} \mathrm{O}\right), \mathrm{Mn}(\mathrm{MnO})$, and Sc concentrations in stream sediments are smaller than those in coastal sea sediments; the Ni contents show an opposite result. Thus, the cumulative probability trends of most elements in coastal sea sediments are different from those of stream sediments. Therefore, the regional geochemical differences (color variation) of most elements in the sea or the land will be obscured if a common class selection is applied to geochemical maps combining the two sample materials. The geochemical patterns displayed in different sample materials using percentiles can be compared directly because the same range (e.g. 90-95\%) implies the same statistical weight, even on different scales (Reimann, 2005).

\section{Comparison of elemental abundance in coastal sea sediment, stream sediment, and Japanese upper crusts}

Figure 4 shows the median concentrations of 41 elements for the stream and coastal sea sediments. These concentrations have been normalized to the continental upper crust data 
(Taylor \& McLennan, 1995). Coastal sea and stream sediments contain water and organic matters that are different from rock samples. For example, Ujiie-Mikoshiba et al. (2006) reported that the lost of ignition at $1000{ }^{\circ} \mathrm{C}$ for $1 \mathrm{~h}$ of 16 stream sediments in northern Japan was $8.1 \%$ average. Their elemental concentrations became systematically lower than those of rock samples. Therefore, each elemental concentration is normalized by $\mathrm{Al}_{2} \mathrm{O}_{3}$ content.

Overall, the coastal sea sediments show a pattern similar to that of the stream sediments. In particular, the relative abundance of $\mathrm{Be}, \mathrm{K}, \mathrm{Rb}, \mathrm{Nb}, \mathrm{Cs}$, light rare earth elements (light REEs), and $\mathrm{Ta}$, which are lithophile elements abundant in felsic rocks, are consistent to one another. This result supports the theory that coastal sea sediments were originally adjacent terrestrial materials. The coastal sea sediments have higher concentrations of $\mathrm{Na}\left(\mathrm{Na}_{2} \mathrm{O}\right), \mathrm{Mg}(\mathrm{MgO})$, $\mathrm{Ca}(\mathrm{CaO})$, and $\mathrm{Sr}$ than stream sediments. This enrichment is caused by calcareous shells and sea salt. Coastal sea sediments have systematically lower concentrations of $\mathrm{Ti}\left(\mathrm{TiO}_{2}\right), \mathrm{V}, \mathrm{Mn}$ $(\mathrm{MnO}), \mathrm{Fe}\left(\mathrm{Fe}_{2} \mathrm{O}_{3}\right), \mathrm{Co}, \mathrm{Cu}$, and $\mathrm{Zn}$, which are lithophile and siderophile elements that are abundant in mafic rocks. $\mathrm{Cu}, \mathrm{Zn}, \mathrm{As}, \mathrm{Mo}, \mathrm{Cd}, \mathrm{Sn}, \mathrm{Sb}, \mathrm{Hg}, \mathrm{Pb}$, and $\mathrm{Bi}$ are chalcophile elements. The abundance of $\mathrm{As}, \mathrm{Mo}, \mathrm{Sb}$, and $\mathrm{Pb}$ in coastal sea sediments is comparable to those of stream sediments. The coastal sea sediments have lower $\mathrm{Cu}, \mathrm{Zn}, \mathrm{Cd}$, and $\mathrm{Sn}$ abundance and higher $\mathrm{Hg}$ and $\mathrm{Bi}$ abundance than stream sediments.

For comparison, the geochemical data of the Japanese upper crust is also portrayed in Fig. 4. This is compiled data from analytical values of 166 rock types distributed in Japan (Togashi et al., 2000). The most important characteristic exhibited is that the elemental abundance of coastal sea and stream sediments are comparable to that of the Japanese upper crust. The Japanese upper crust is enriched in $\mathrm{Li}, \mathrm{Sc}, \mathrm{V}, \mathrm{Cr}, \mathrm{Mn}(\mathrm{MnO}), \mathrm{Co}, \mathrm{Ni}, \mathrm{As}, \mathrm{Sb}$, and $\mathrm{Cs}$ and poor in $\mathrm{Na}\left(\mathrm{Na}_{2} \mathrm{O}\right), \mathrm{P}\left(\mathrm{P}_{2} \mathrm{O}_{5}\right), \mathrm{K}\left(\mathrm{K}_{2} \mathrm{O}\right), \mathrm{Sr}, \mathrm{Nb}, \mathrm{La}, \mathrm{Ce}$, and Ta as compared to the upper continental crust. These chemical compositions reflect the geology of Japan. Sedimentary rocks in the accretionary complexes are abundant in $\mathrm{Li}, \mathrm{As}, \mathrm{Sb}, \mathrm{Cs}, \mathrm{Tl}$, and $\mathrm{Bi}$. Mafic volcanic rocks with high concentrations of $3 \mathrm{~d}$ transition metals and unmetamorphosed sedimentary rocks enriched in As and $\mathrm{Sb}$ are distributed more widely in Japan as compared to the continental crust (Togashi et al., 2000; Ujiie-Mikoshiba et al., 2006). Rocks associated with mineral deposits are not compiled in the Japanese upper crust. The abundance of chalcophile elements such as $\mathrm{Cu}, \mathrm{Zn}, \mathrm{Cd}$, and $\mathrm{Pb}$ is poorer than that in stream and coastal sea sediments. Except for these elements, stream and coastal sea sediments are useful to assess the chemical composition of the earth's surface instead of using rock samples.

\section{Particle size dependence of elemental concentrations in coastal sea sediments}

As we described above, stream sediments retained for geochemical mapping were sieved with $180-\mu \mathrm{m}$ mesh and composed of fine sand and very fine sand. In contrast, coastal sea sediments used here vary in size. In some places, the spatial distribution of elemental concentrations in the marine environment is predominantly determined by the variation of particle sizes (Ohta et al., 2004b). To validate this point, the effect of particle size on elemental concentrations in coastal sea sediments is evaluated.

Figure 5 shows the median elemental concentrations plotted against nine types of sediment particle sizes. It can be observed that most of the elemental concentrations increase with a decrease in the particle size, and become constant through sandy silt to silty clay. However, there are some exceptions to this rule. Calcium $(\mathrm{CaO})$ and $\mathrm{Sr}$ are abundant in very coarse and coarse sand because they contain a large amount of calcareous shells, shell fragments, 


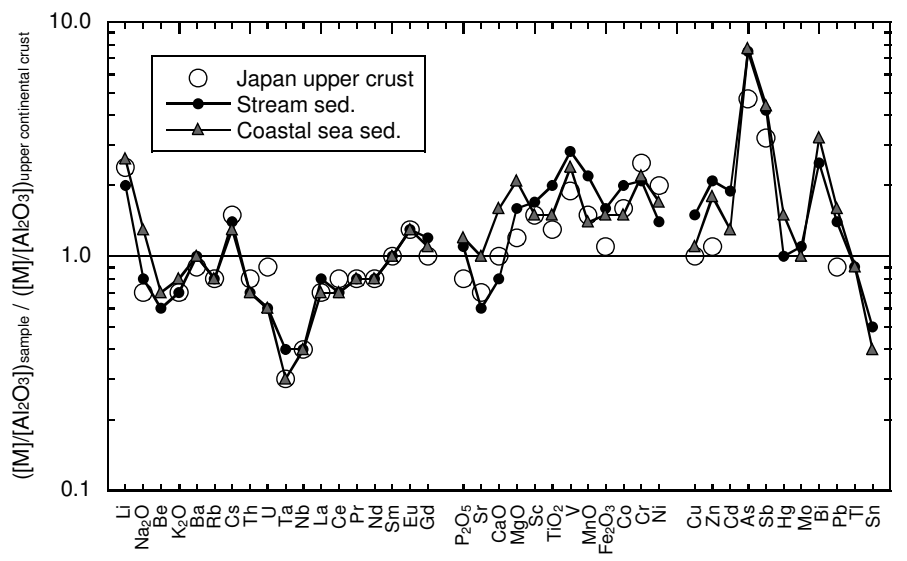

Fig. 4. Chemical compositions of coastal sea sediments, stream sediments, and the Japanese upper crust normalized to the continental upper crust data. The [M] means elemental concentration

and foraminiferas. The concentrations of $\mathrm{Mn}(\mathrm{MnO}), \mathrm{Fe}\left(\mathrm{Fe}_{2} \mathrm{O}_{3}\right)$, and $\mathrm{Co}$ are high in coarse and medium sands, which indicate the presence of Fe-Mn oxides. The $\mathrm{Mn}^{2+}, \mathrm{Fe}^{2+}$, and $\mathrm{Co}^{2+}$ are easily oxidized in water and precipitate on coarse grains. Little systematic differences are found in $\mathrm{Al}\left(\mathrm{Al}_{2} \mathrm{O}_{3}\right), \mathrm{Ti}\left(\mathrm{TiO}_{2}\right), \mathrm{Y}$, and heavy REEs. The $\mathrm{Mg}(\mathrm{MgO}), \mathrm{V}, \mathrm{Mn}(\mathrm{MnO})$, and As are enriched both in coarse sand and very fine sediments (silt and clay). Except for these elements, most elemental concentrations increase with decreasing particle size. This trend is attributed mainly to the dilution effect by quartz and calcareous materials. Finer sediments are distributed in the outer sea. We must pay attention to the fact that elemental concentrations become gradually higher with increasing distance out to sea because particle size distribution produces geochemical graduation in marine environments irrespective of mass transfer from land to sea.
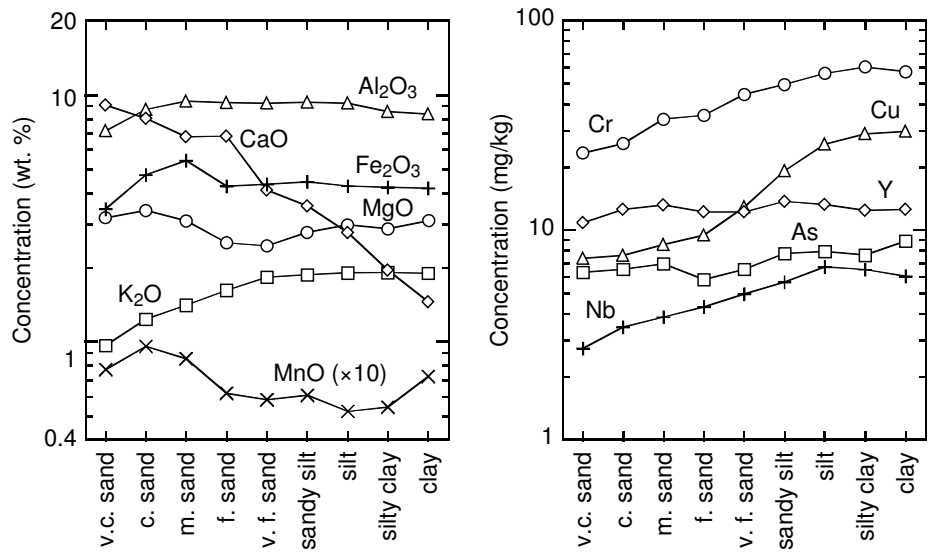

Fig. 5. Median of elemental concentrations of coastal sea sediments according to the particle size classification. The abbreviations v. c. sand, c. sand, m. sand, f. sand, v. f. sand refer to vary coarse sand, coarse sand, medium sand, fine sand, and very fine sand, respectively 


\section{Spatial distribution patterns of elemental concentrations in coastal seas and adjoining terrestrial areas}

The spatial distribution of elements in the terrestrial area is predominantly controlled by parent lithology. The influence of mineral deposits and anthropogenic activity are restricted in small areas, but they cause extreme enrichments of elements. The analysis of controlling factors using the geographic information system and statistical analysis demonstrate that the following seven factors are the most dominant cause for the spatial distribution of elemental concentrations (Ohta et al., 2004a, b, 2005a, b):

a. Accretionary complexes (sedimentary rocks): $\mathrm{Li}, \mathrm{Be}, \mathrm{K}\left(\mathrm{K}_{2} \mathrm{O}\right), \mathrm{Rb}, \mathrm{Cs}$, and $\mathrm{Tl}$

b. Felsic volcanic rocks: $\mathrm{Be}, \mathrm{K}\left(\mathrm{K}_{2} \mathrm{O}\right), \mathrm{Rb}, \mathrm{Cs}, \mathrm{Ba}$, and $\mathrm{Tl}$

c. Granitic rocks: $\mathrm{Be}, \mathrm{Na}\left(\mathrm{Na}_{2} \mathrm{O}\right), \mathrm{K}\left(\mathrm{K}_{2} \mathrm{O}\right), \mathrm{Nb}, \mathrm{Sn}, \mathrm{REEs}, \mathrm{Ta}$, Th, and $\mathrm{U}$

d. Mafic volcanic rocks: $\mathrm{Mg}(\mathrm{MgO}), \mathrm{P}\left(\mathrm{P}_{2} \mathrm{O}_{5}\right), \mathrm{Ca}(\mathrm{CaO}), \mathrm{Sc}, \mathrm{Ti}\left(\mathrm{TiO}_{2}\right), \mathrm{V}, \mathrm{Cr}, \mathrm{Mn}(\mathrm{MnO}), \mathrm{Fe}$ $\left(\mathrm{Fe}_{2} \mathrm{O}_{3}\right), \mathrm{Co}, \mathrm{Ni}, \mathrm{Cu}$, and $\mathrm{Zn}$

e. Ultramafic rocks: $\mathrm{Mg}(\mathrm{MgO}), \mathrm{Cr}, \mathrm{Co}$, and $\mathrm{Ni}$

f. Mineral deposits: $\mathrm{Cu}, \mathrm{Zn}, \mathrm{As}, \mathrm{Mo}, \mathrm{Cd}, \mathrm{Sn}, \mathrm{Sb}, \mathrm{Hg}, \mathrm{Pb}$, and $\mathrm{Bi}$

g. Anthropogenic activities: $\mathrm{P}\left(\mathrm{P}_{2} \mathrm{O}_{5}\right), \mathrm{Cr}, \mathrm{Co}, \mathrm{Ni}, \mathrm{Cu}, \mathrm{Zn}, \mathrm{As}, \mathrm{Mo}, \mathrm{Cd}, \mathrm{Sn}, \mathrm{Sb}, \mathrm{Hg}$, and $\mathrm{Pb}$

Figures 6 and 7 show geochemical maps of $\mathrm{K}\left(\mathrm{K}_{2} \mathrm{O}\right), \mathrm{Ca},(\mathrm{CaO}), \mathrm{Sc}$, and $\mathrm{Cu}$. Overall, elemental concentrations are continuous between the terrestrial area and the coastal sea area. $\mathrm{K}\left(\mathrm{K}_{2} \mathrm{O}\right)$ is abundant in the eastern Honshu Island and $\mathrm{Sc}$ has a reverse distribution as compared to $\mathrm{K}\left(\mathrm{K}_{2} \mathrm{O}\right)$. Their spatial distributions in the marine environment correspond well to the adjoining terrestrial area, where $\mathrm{K}\left(\mathrm{K}_{2} \mathrm{O}\right)$ is enriched in the area covered by accretionary complexes, felsic volcanic, and granitic rocks and $\mathrm{Sc}$ is enriched in the area covered by mafic volcanic rocks (Fig. 1b). Figure 4 suggests that $\mathrm{K}\left(\mathrm{K}_{2} \mathrm{O}\right)$ and $\mathrm{Sc}$ abundances in coastal seas match that of stream sediments and the Japanese upper crust materials. It is obvious that marine sediments originated from stream sediments on the adjacent terrestrial area.

In contrast, the spatial distribution of $\mathrm{Ca}(\mathrm{CaO})$ and $\mathrm{Cu}$ concentrations in coastal seas is not continuous to that in terrestrial areas, which is different from the cases of $\mathrm{K}\left(\mathrm{K}_{2} \mathrm{O}\right)$ and Sc. The $\mathrm{Ca}(\mathrm{CaO})$ and $\mathrm{Cu}$ are enriched in stream sediments derived from mafic volcanic rocks, which are similar to Sc. In the coastal sea, especially in shallow water depth, marine sediments are composed of shell fragments and foraminifera tests. The extremely high $\mathrm{Ca}$ $(\mathrm{CaO})$ contents in such calcareous materials hide the contribution of $\mathrm{Ca}(\mathrm{CaO})$ in sediments derived from the adjacent terrestrial area. In contrast, the $\mathrm{Cu}$ concentration is low in shallow water depths but increases with water depth, except at the inner basin. The increasing trend of $\mathrm{Cu}$ concentrations in marine sediments also corresponds to systematic changes in particle size (Fig. 5). Although we will discuss the details later, early diagenetic processes and organic matters elevate $\mathrm{Mn}(\mathrm{MnO}), \mathrm{Cu}, \mathrm{Mo}, \mathrm{Cd}, \mathrm{Sb}, \mathrm{Hg}, \mathrm{Pb}$, and $\mathrm{U}$ concentrations in silty and clayey sediments. The abundance of $\mathrm{Ca}(\mathrm{CaO})$ and $\mathrm{Cu}$ in coastal sea sediments is different from that in stream sediments because of the input of biogenic materials and early diagenetic process. Therefore, these geochemical maps do not reflect the horizontal mass transfer process.

\section{Mass transport processes}

\subsection{Mass transport processes: contribution of terrestrial materials and transportation of coastal sediments by a gravity flow or by an oceanic current}

The elemental abundance pattern and regional geochemical maps support mass transfer from land to sea. Next, we discuss the details of the horizontal mass transfer process using 


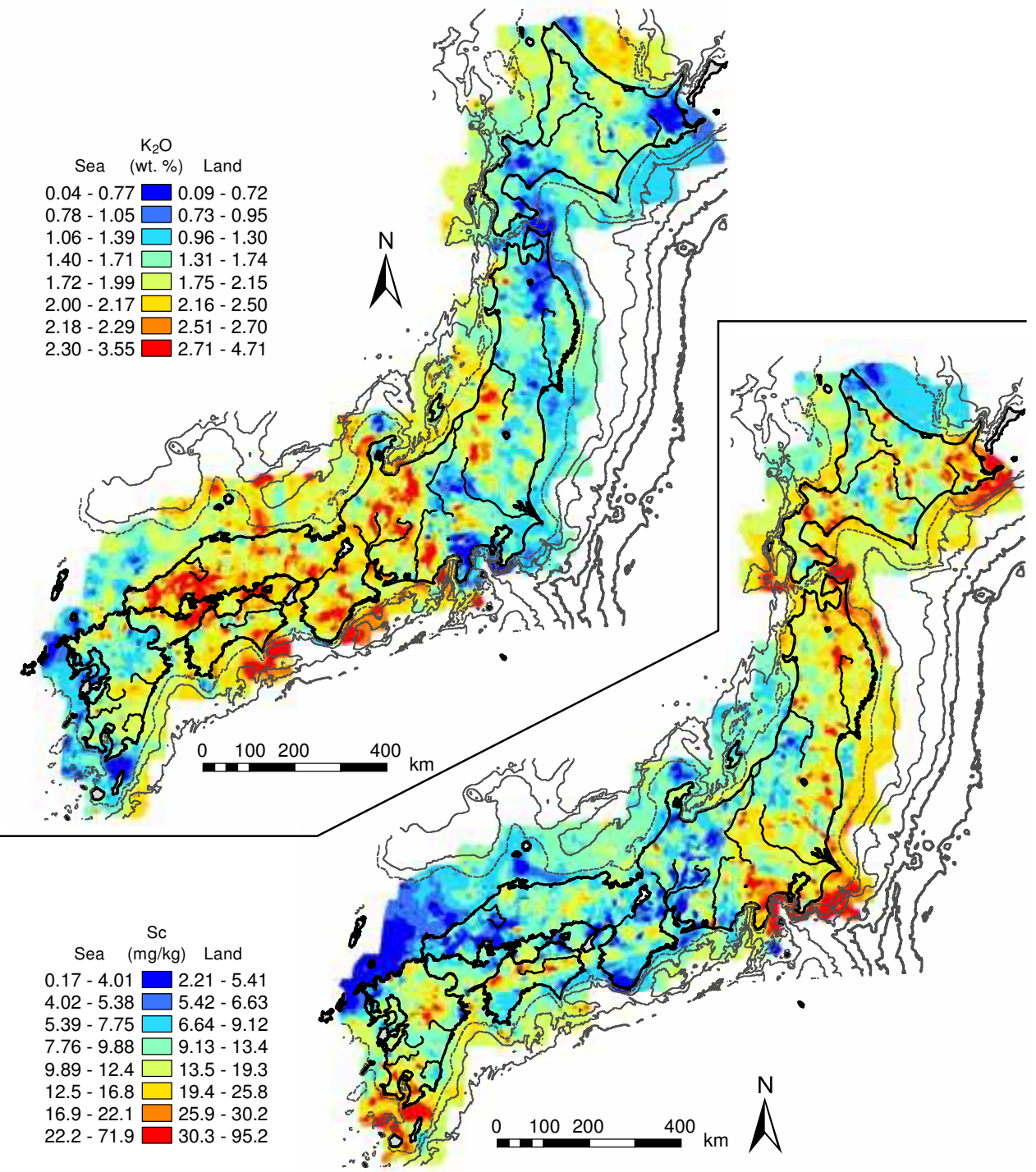

Fig. 6. Geochemical maps of $\mathrm{K}\left(\mathrm{K}_{2} \mathrm{O}\right)$ and $\mathrm{Sc}$ in stream and coastal sea sediments. Small islands are expressed as slightly darkened gray areas

local geochemical maps. Figure 8 shows some examples of visible mass transfers from land to sea. The area is characterized by the narrow continental shelf and the Toyama submarine valley, whose water depth is over $1,000 \mathrm{~m}$, and is $500 \mathrm{~km}$ long. In the terrestrial area, granitic outcrops influence the distribution of $\mathrm{Be}, \mathrm{Na}\left(\mathrm{Na}_{2} \mathrm{O}\right), \mathrm{K}\left(\mathrm{K}_{2} \mathrm{O}\right), \mathrm{Rb}, \mathrm{Y}$, rare earth elements (REEs), $\mathrm{Tl}, \mathrm{Th}$, and $\mathrm{U}$ (see $\mathrm{K}_{2} \mathrm{O}$ in Fig. 8). Ultramafic rocks (mainly serpentinite) associated with accretionary complexes occupy only a small area. However, these rocks are 


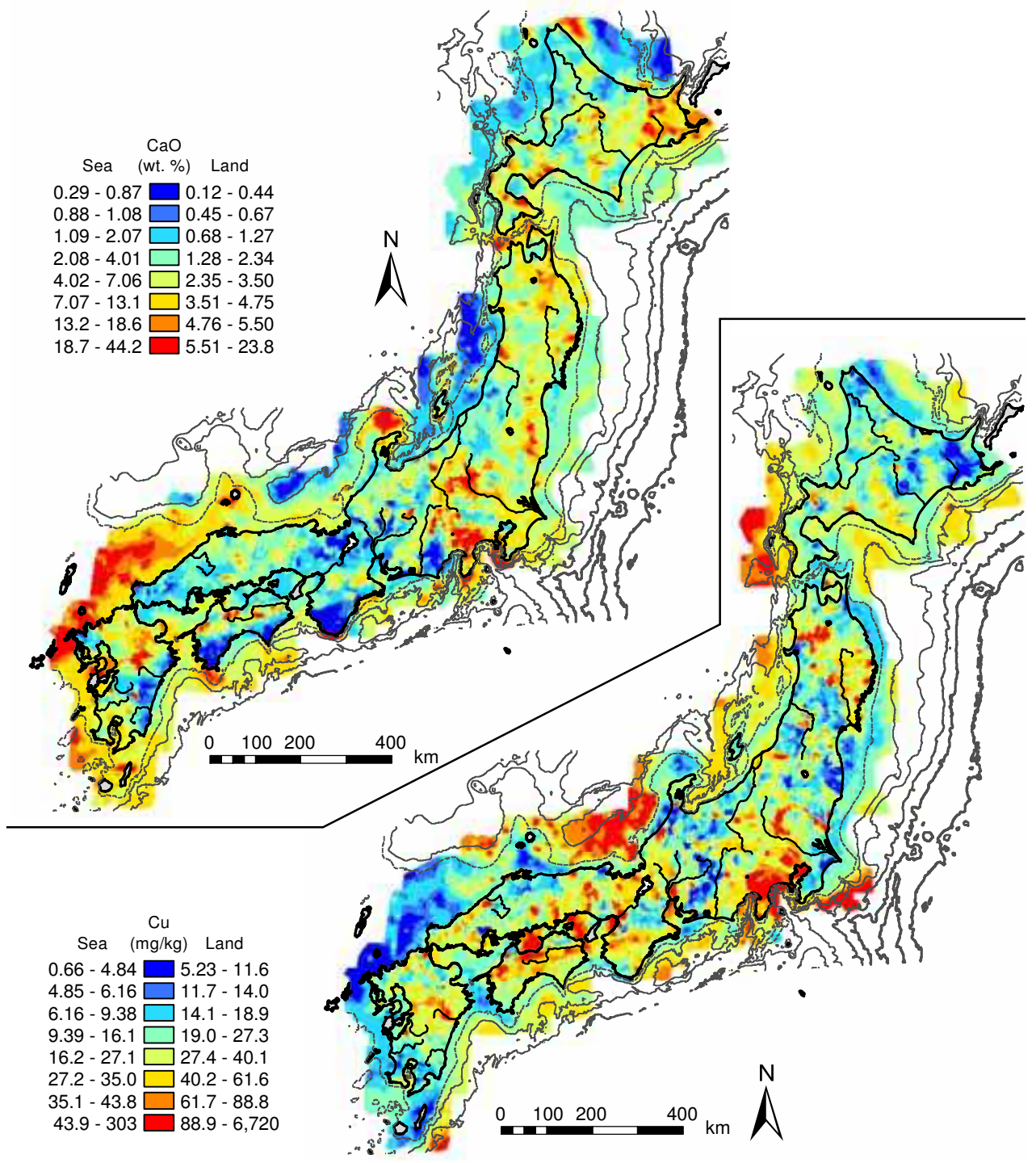

Fig. 7. Geochemical maps of $\mathrm{Ca}(\mathrm{CaO})$ and $\mathrm{Cu}$ in stream and coastal sea sediments. Small islands are expressed as slightly darkened gray areas

the source of the extremely high concentrations of $\mathrm{Mg}(\mathrm{MgO}), \mathrm{Cr}, \mathrm{Co}$, and $\mathrm{Ni}$ (see $\mathrm{Cr}$ in Fig. 8). It can be observed that the distribution of high $\mathrm{K}\left(\mathrm{K}_{2} \mathrm{O}\right)$ and $\mathrm{Cr}$ concentrations continues from land to sea. The distribution of $\mathrm{K}\left(\mathrm{K}_{2} \mathrm{O}\right)$ in coastal seas suggests that sediments supplied through rivers initially spread out in a fan from the continental shelf and slope $(\sim 20 \mathrm{~km})$. In contrast, the spatial distribution of high levels of $\mathrm{Mg}(\mathrm{MgO}), \mathrm{Cr}, \mathrm{Co}$, and $\mathrm{Ni}$ contents extends to the outer sea along the deep valley (Fig. 8). Sediments deposited on an oceanic floor with depths of several hundred meters are rarely moved by a tidal wave and an oceanic current. 
They are conveyed by the gravity flow that occurs over $100 \mathrm{~km}$ through the slope and the Toyama submarine canyon. The high concentration of $\mathrm{K}\left(\mathrm{K}_{2} \mathrm{O}\right)$ along the submarine canyons does not extend as far as the high concentration of $\mathrm{Cr}$ area. $\mathrm{K}\left(\mathrm{K}_{2} \mathrm{O}\right)$ is possibly associated with coarse particles such as K-feldspar, which is not transported far. In contrast, $\mathrm{Cr}$ is associated with fine particles such as serpentine, chromite, and chromium spinel.

In the northern part of Japan, fine sediments supplied from rivers are conveyed by an oceanic current up to a distance of 100-200 km along the coast. The Hokkaido Island, which is located in the northernmost region of Japan, is characterized by a wide continental shelf. The distribution of sediments is influenced strongly by a coastal current. Distribution of high $\mathrm{Cr}$ and $\mathrm{Ni}$ concentrations extends over $200 \mathrm{~km}$ on the shelf (see dotted arrows numbered 1 for $\mathrm{Cr}$ in Fig. 9). Underlying ultramafic rocks (mainly serpentinite) in the watershed upstream of rivers are the origin of the $\mathrm{Cr}$ and $\mathrm{Ni}$ enrichments on the shelf. However, the coastal current direction changes with the seasons. The extension of high $\mathrm{Cr}$ and $\mathrm{Ni}$ concentration to the north and northwest direction is explained by two reasons. Large amounts of sediments are supplied from rivers especially during spring and summer because of snowmelt (Katayama, 2008). The northward coastal current prevails during those seasons and transports large amounts of sediments associated with $\mathrm{Cr}$ and $\mathrm{Ni}$ northward (Katayama, 2008). Serpentine, chromite, and chromium spinel, including $\mathrm{Cr}$ and $\mathrm{Ni}$, have very fine minerals (clay size) that can be transported long distances.
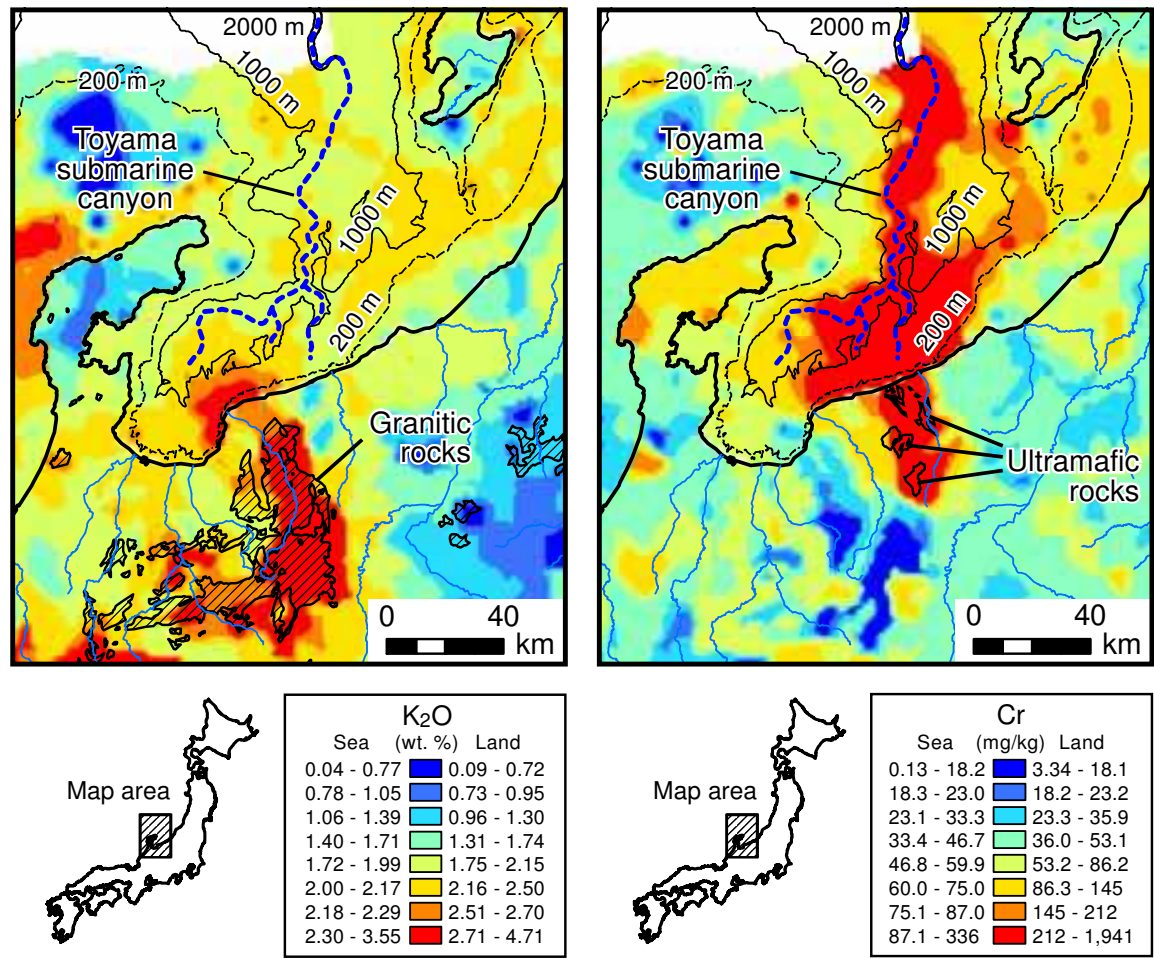

Fig. 8. Geochemical maps of $\mathrm{K}\left(\mathrm{K}_{2} \mathrm{O}\right)$ and $\mathrm{Cr}$ in the Hokuriku region 
In the southern part of the Hokkaido Island, high-concentration areas of $\mathrm{Li}, \mathrm{Be}, \mathrm{Mg}(\mathrm{MgO})$, $\mathrm{Al}\left(\mathrm{Al}_{2} \mathrm{O}_{3}\right), \mathrm{Ti}\left(\mathrm{TiO}_{2}\right), \mathrm{V}, \mathrm{Cr}, \mathrm{Fe}\left(\mathrm{T}-\mathrm{Fe}_{2} \mathrm{O}_{3}\right), \mathrm{Co}, \mathrm{Ni}, \mathrm{Nb}$, light REEs, and Ta exist in the shelf and adjoining terrestrial area (see a dotted arrow numbered 2 for $\mathrm{Cr}$ and a circle numbered 1 for $\mathrm{Nb}$ in Fig. 9). These spatial distribution patterns suggest that marine sediments are transported northwestward. The coastal current direction in this region also changes with the seasons (Kuroda et al., 2006). Sediments are supplied in large amounts from rivers during spring-summer because of snowmelt. At that time, the northwestward coastal current prevails (Kuroda et al., 2006), so that the sediments are transported northwestward. Sediments deposited on the shelf are further moved by gravity flows to the deep sea (the Hidaka Trough). In contrast, the areas of $\mathrm{Nb}$, REEs, and Ta enrichment are limited to the near shore. Granitic rocks host $\mathrm{Li}, \mathrm{Be}, \mathrm{Nb}$, REEs, and Ta, but they are scarce on the Hokkaido Island where mafic volcanic rocks and andesitic-dacitic pyroclastic rocks dominant the lithology. It is possible that sediments enriched in these elements supplied to the coastal sea are not abundant. Otherwise, $\mathrm{Nb}$, REEs, and Ta are associated with coarse sediments, which are not transported far by the coastal current. In contrast, $\mathrm{Mg}(\mathrm{MgO}), \mathrm{Cr}, \mathrm{Co}$, and $\mathrm{Ni}$ are possibly included in fine minerals (such as serpentine), which are transported more easily by the coastal current.
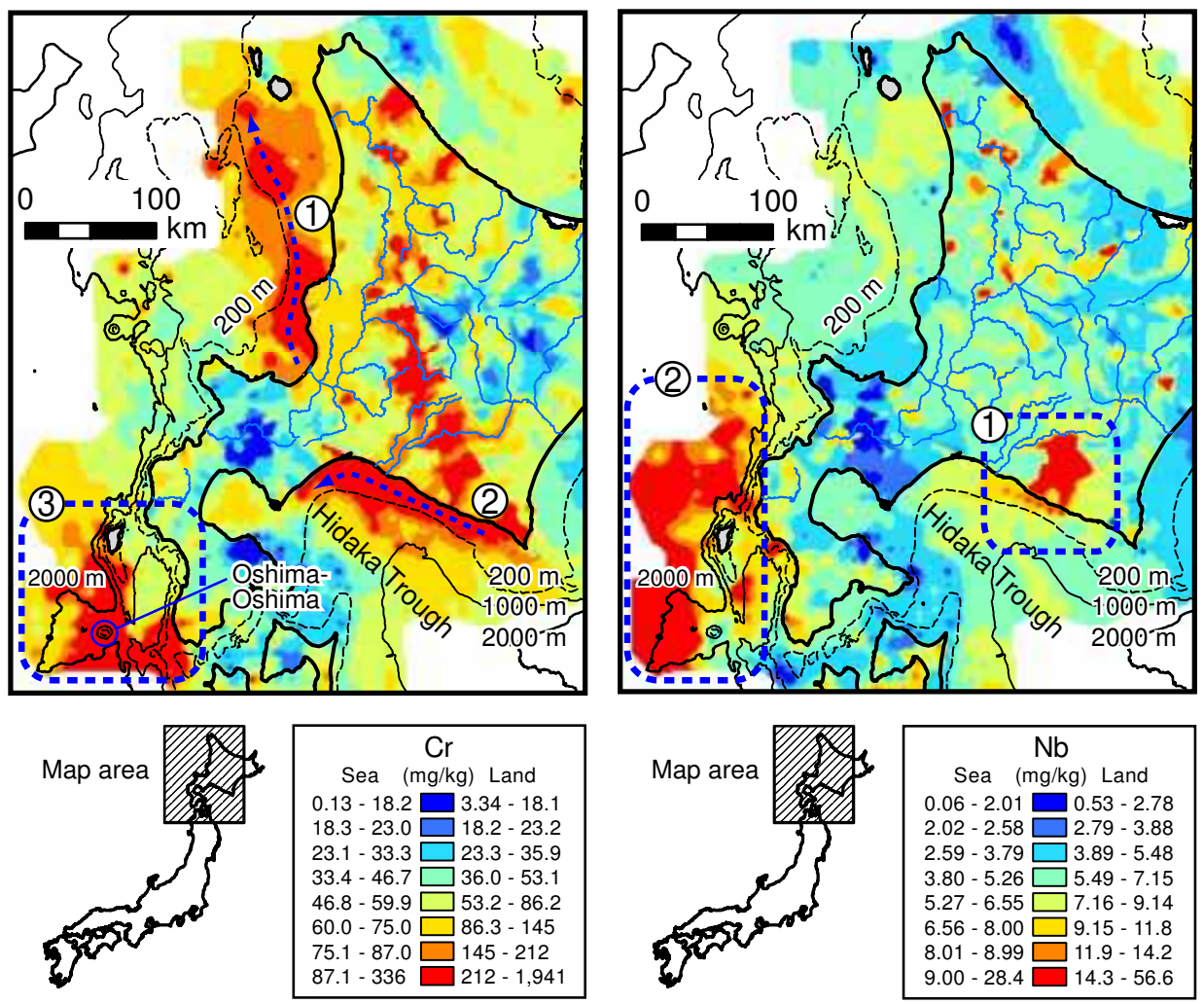

\begin{tabular}{|c|c|}
\hline \multicolumn{2}{|c|}{$\mathrm{Nb}$} \\
\hline $0.06-2.01$ & $0.53-2.78$ \\
\hline $2.02-2.58$ & $2.79-3.88$ \\
\hline $2.59-3.79$ & $3.89-5.48$ \\
\hline $3.80-5.26$ & $5.49-7.15$ \\
\hline $5.27-6.55$ & | $7.16-9.14$ \\
\hline $6.56-8.00$ & $9.15-11.8$ \\
\hline $8.01-8.99$ & $11.9-14.2$ \\
\hline $9.00-28.4$ & $14.3-56.6$ \\
\hline
\end{tabular}

Fig. 9. Geochemical maps of $\mathrm{Cr}$ and $\mathrm{Nb}$ in the Hokkaido region 
The mass transfer process of marine sediments is also influenced by a current rip and a periodical current. Figure 10 portrays the geochemical map of $\mathrm{Cr}$ around the Shikoku Island. Greenstones and ultramafic rocks (mainly serpentinite) in accretionary complexes host these elements in the adjacent terrestrial area. It can be observed that the silty and clayey sediments are distributing on the shelf and basin. These fine sediments have high $\mathrm{Mg}$ $(\mathrm{MgO}), \mathrm{Cr}, \mathrm{Co}$, and $\mathrm{Ni}$ concentrations. The distribution pattern of high $\mathrm{Cr}$ concentrations follows a reverse J-shape (see a circle numbered 1 in Fig. 10). That characteristic distribution is explained by the sedimentation process occurring between two water masses and a gravity flow. Ikehara (1988) explained that the silty and clayey sediments supplied from rivers deposit on the shelf where the boundary of superjacent waters and oceanic water resides. Oceanic water is possibly a counter current of the Kuroshio Current. These fine sediments deposited on the shelf are further conveyed to the deep-sea basin by a gravity flow. In contrast, the NNW-SSE trend of high $\mathrm{Mg}(\mathrm{MgO}), \mathrm{Cr}, \mathrm{Co}$, and $\mathrm{Ni}$ concentrations is found in the straight region (see a circle numbered 2 in Fig. 10). The feature clearly indicates that the fine sediments abundant in $\mathrm{Mg}(\mathrm{MgO}), \mathrm{Cr}, \mathrm{Co}$, and $\mathrm{Ni}$ are supplied mainly from the Shikoku Island and conveyed by a periodical current.

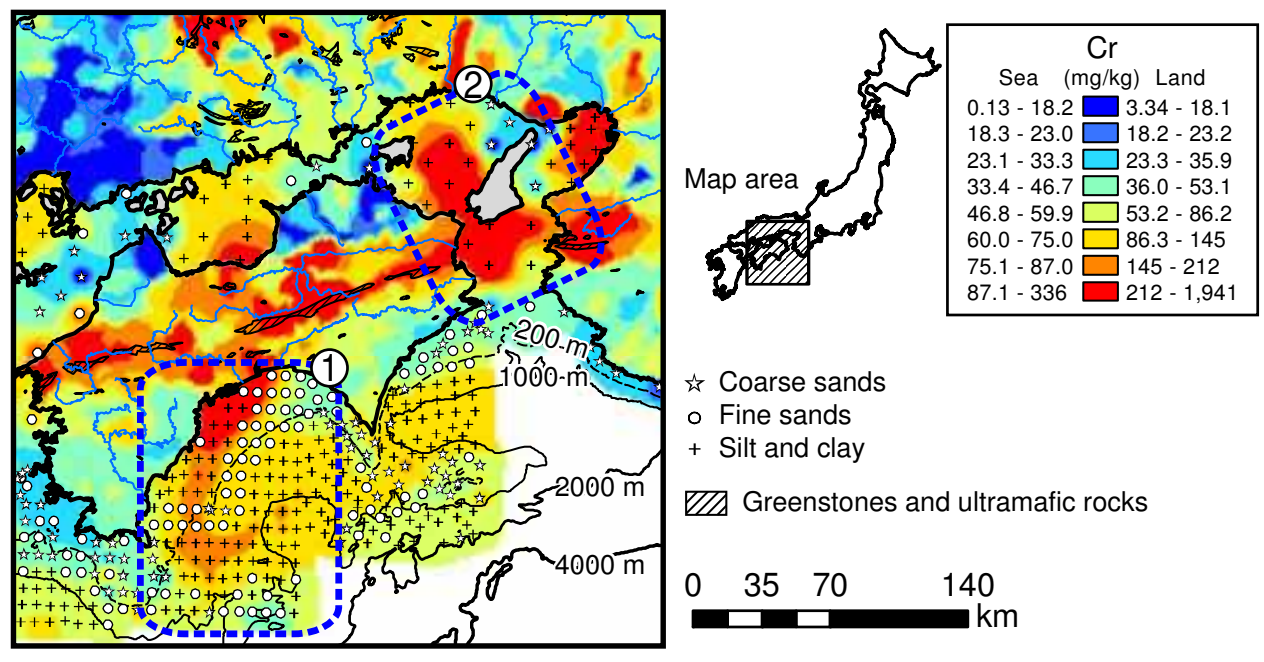

Fig. 10. Geochemical map of $\mathrm{Cr}$ around the Shikoku Island

The mass movement in the sea reflects the sea topography and is followed by a gravity flow and an oceanic current. However, the continuous distribution of elements between the land and sea is not always found everywhere. Relict sediments distributing on the shelf and slope might conceal the modern mass transfer process. Their distribution is indicative of the past mass transfer process because they were deposited during the last glacial age and the early transgression age. Ohta et al. $(2007 ; 2010)$ found, however, that the influence on elemental distribution is restricted in small areas. Instead, they suggest that continuous distribution is found in the case where parent lithology covers widely adjacent terrestrial areas. Otherwise a rock type having extremely high concentrations of elements existed on land. Figures 8, 9, and 10 represent the latter case. In addition, the mass transfer process in the marine 
environment is traceable up to $30-50 \mathrm{~km}$ for all geochemical maps, except for $\mathrm{Cr}$ and $\mathrm{Ni}$ maps. According to Ohta et al. (2002; 2007), variations of chemical compositions in samples become small by the following order,

Parent lithology > stream sediment $>$ sandy marine sediment $>$ clayey marine sediment

Finer particles are mixed well and become homogeneous as compared to coarser particles because they take a longer time to deposit as compared to coarse particles according to Stokes' law. It becomes hard to find the systematic differences between elemental concentrations in finer sediments during the mass transfer process. For these reasons, a geochemical map is effective to elucidate short-range transfer processes.

\subsection{Mass transport processes: volcanic materials transported through the atmosphere}

Japan possesses many active volcanoes and both terrestrial and marine areas are strongly influenced by volcanic eruptions. Volcanic materials, mainly volcanic ash, are transported extensively through the atmosphere. A volcanic eruption is episodic so that the occurrence is concealed by active erosion or active sedimentation processes. Conversely, the distribution of volcanic materials found in geochemical maps may be used to determine where modern sediments are supplied. Furthermore, they provide a sedimentation rate of modern sediments and the presence of a strong bottom sea current that sweeps away fine recent sediments. In this chapter, we discuss the mass transport process of recent volcanic materials erupted in the Holocene.

The distribution pattern of high $\mathrm{Al}\left(\mathrm{Al}_{2} \mathrm{O}_{3}\right), \mathrm{Ti}\left(\mathrm{TiO}_{2}\right), \mathrm{Fe}\left(\mathrm{T}-\mathrm{Fe}_{2} \mathrm{O}_{3}\right), \mathrm{Sc}, \mathrm{Cr}, \mathrm{Co}, \mathrm{Ni}, \mathrm{Sr}$, and $\mathrm{Eu}$ contents follow an L shape around the southeast part of Hokkaido Island (see the circle numbered in 3 for $\mathrm{Cr}$ in Fig. 9). The feature suggests the contribution of basaltic-andesitic materials, including ultramafic inclusions erupted in 1741-1742 from a volcanic island (Oshima-Oshima island) (Inouchi et al., 1995). The lower concentration of $\mathrm{Cr}$ in the north part of the circle numbered 3 in Fig. 9 might be caused by modern turbidity sediments supplied from adjacent terrestrial areas and steep slopes in the coastal sea.

The deep basin located in the western part of the Hokkaido Island is widely influenced by distant volcanic activity, i.e. regional tephra (Machida, 1999). Core profiles suggest that many tephra layers are included in sediment core samples. The Baegdusan-Tomakomai tephra (B-Tm) is supplied from the Baegdusan Volcano of North Korea 1,000 years ago, which is $900 \mathrm{~km}$ away from Hokkaido Island (Machida, 1999). It is characterized by having extremely higher $\mathrm{Zn}, \mathrm{Zr}, \mathrm{Nb}$, REEs (except $\mathrm{Eu}$ ), Hf, Ta, Th, and $\mathrm{U}$ concentrations and lower $\mathrm{Sc}, \mathrm{Ti}\left(\mathrm{TiO}_{2}\right), \mathrm{V}, \mathrm{Cr}, \mathrm{Ni}, \mathrm{Sr}$, and $\mathrm{Ba}$ concentrations than the other tephras found in northern Japan (Fukuoka, 1991; Kikkawa et al., 1989). Actually, there is an extreme enrichment of Zr, $\mathrm{Nb}$, REEs, Hf, Ta, and Th in the western part of the Hokkaido Island (see a circle numbered in 2 for $\mathrm{Nb}$ in Fig. 9). Although the B-Tm tephra widely covers northern Japan, the enrichments of $\mathrm{Zr}, \mathrm{Nb}$, REEs, Hf, Ta, and Th are found only in deep basins located in the west. This fact is explained by the increase of the sedimentation rate from west to east. The B-Tm tephra layer is found in sediment cores at a depth of $0-25 \mathrm{~cm}$ in the western part and at a depth of $128-176 \mathrm{~cm}$ in the eastern part (Noda et al., 2007). Because the sedimentation rate is very slow in the deep basins, we can determine the past volcanic activity from geochemical maps.

Regional tephras supplied from Japanese giant volcanoes are found all over the place as well as in the B-Tm tephra (Machida, 1999). The Kikai Caldera, which was formed by large-scale violent eruptions 7,300 years ago, is located in the southern part of the Kyushu Island (Fig. 
11). The pyroclastic flows from the Kikai Caldera extended over $100 \mathrm{~km}$, with some of them reaching the Kyushu Island. Its volcanic ash covered all of Japan (Machida, 1999). The coarse sediments distributed in the southern part of the Kyushu Island contained volcanic materials including pumice. Strong bottom currents flowing from west to east sweep away fine sediments there. On account of this, the past volcanic materials supplied from the Kikai Caldera eruptions remain in the region. It is possible that a part of them have been supplied from the southern Kyushu Island, where pyroclastic flow deposits erupted from giant volcanoes during the Pleistocene era (26,000-110,000 years ago). The distribution of high $\mathrm{Mg}$ $(\mathrm{MgO}), \mathrm{Ti}\left(\mathrm{TiO}_{2}\right), \mathrm{Mn}(\mathrm{MnO}), \mathrm{Fe}\left(\mathrm{Fe}_{2} \mathrm{O}_{3}\right), \mathrm{Sc}, \mathrm{V}, \mathrm{Co}$, and $\mathrm{Zn}$ concentrations correspond fairly well with that of the coarse sediments (Fig. 11). These elements are not highly abundant in the fine sediments located in the northern and southeastern regions of the Kikai Caldera, which suggests that terrestrial materials free of volcanic materials were deposited here.

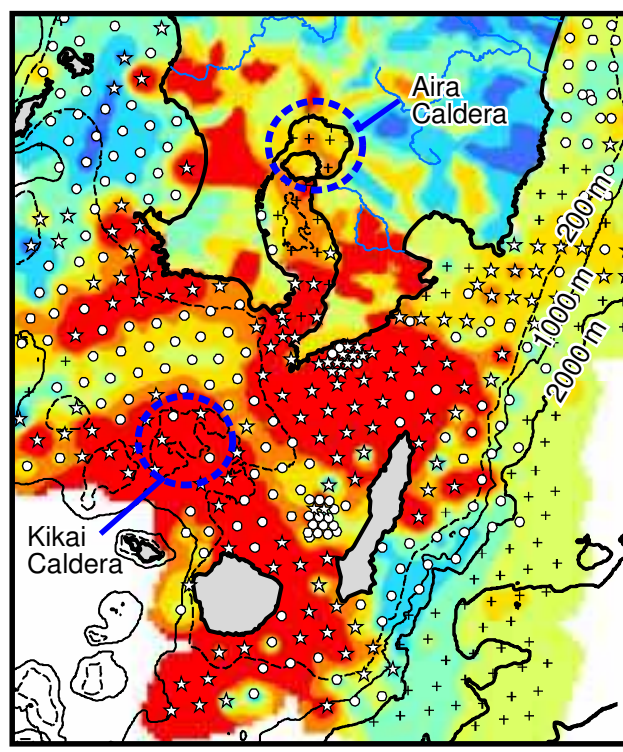

Coastal sea sediments

is Coarse sands

- Fine sands

+ Silt and clay

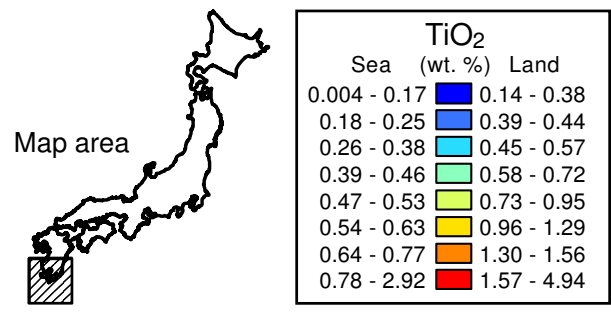

Fig. 11. Geochemical map of $\mathrm{Ti}\left(\mathrm{TiO}_{2}\right)$ in the southern part of the Kyushu Island

\subsection{Mass transport processes: contribution of metalliferous deposits and anthropogenic activity}

$\mathrm{Cu}, \mathrm{Zn}, \mathrm{As}, \mathrm{Mo}, \mathrm{Cd}, \mathrm{Sn}, \mathrm{Sb}, \mathrm{Hg}, \mathrm{Pb}$, and $\mathrm{Bi}$ are chalcophile elements that are highly enriched in stream sediments associated with metalliferous deposits and anthropogenic activity. The spatial distribution of these elements is of environmental interest. Figure 12 shows the spatial distribution of $\mathrm{Cd}$ in the northern and the southeastern parts of the Honshu Island. Numerous Kuroko-style deposits occur in the northern part of the Honshu Island. High elevated $\mathrm{Cu}, \mathrm{Zn}, \mathrm{As}, \mathrm{Cd}, \mathrm{Sb}, \mathrm{Pb}, \mathrm{Hg}$, and $\mathrm{Bi}$ concentrations of stream sediments are present in the region (Ujiie-Mikoshiba et al., 2006). However, no enrichment of these elements, except for $\mathrm{Zn}$ and $\mathrm{Pb}$, is found in the adjoining coastal seas (see the circle numbered in 1 for $\mathrm{Cd}$ in Fig. 12a). The same trend is found around the Shimokita Peninsula where the active 
hydrothermal field is located and a metalliferous deposit is currently forming. We see no enrichment of $\mathrm{Cu}, \mathrm{As}, \mathrm{Cd}, \mathrm{Sb}, \mathrm{Hg}$, and $\mathrm{Bi}$ in the coastal seas and bays around the Shimokita Peninsular (see the circle numbered in 2 for $\mathrm{Cd}$ in Fig. 12a). These facts suggest that sulfide minerals are not supplied directly to coastal seas because the sulfide ores are oxidized, consequently releasing $\mathrm{Cu}, \mathrm{Zn}, \mathrm{As}, \mathrm{Cd}, \mathrm{Sb}, \mathrm{Pb}$, and $\mathrm{Bi}$ during transport from terrestrial areas to coastal waters (Hudson-Edwards et al., 1996). It is also possible that $\mathrm{Zn}$ and $\mathrm{Pb}$ sulfides are extremely resistant to weathering or that their mass concentrations are the highest among these metals. Alternatively, aqueous $\mathrm{Zn}$ and $\mathrm{Pb}$ are easily sorbed on the sediment surface in coastal seas.
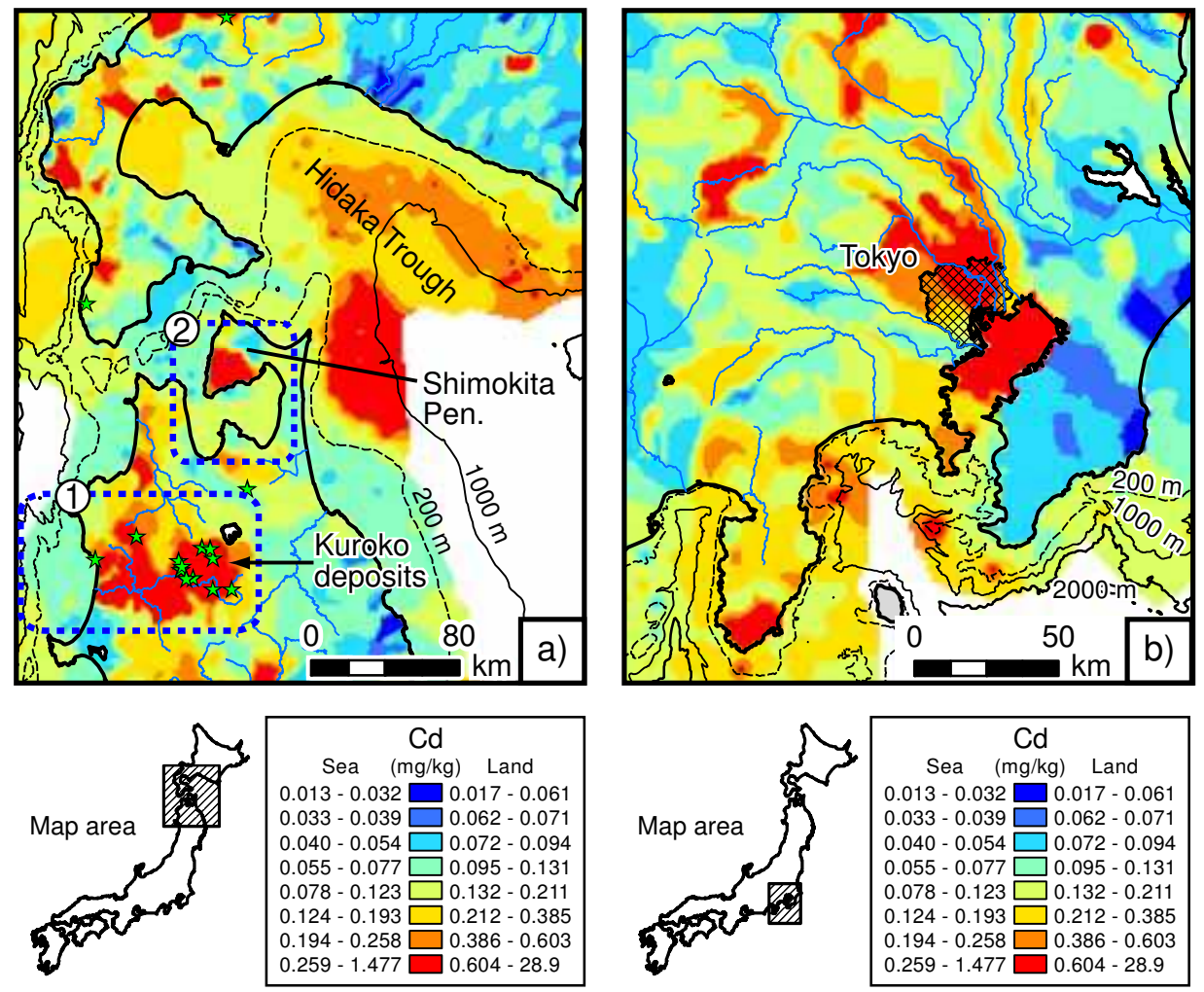

Fig. 12. Geochemical maps of $\mathrm{Cd}$

In contrast, the influence of anthropogenic activity on geochemical maps is somewhat different from that of metalliferous deposits. The $\mathrm{P}\left(\mathrm{P}_{2} \mathrm{O}_{5}\right), \mathrm{Cr}, \mathrm{Ni}, \mathrm{Cu}, \mathrm{Zn}, \mathrm{Mo}, \mathrm{Cd}, \mathrm{Sn}, \mathrm{Sb}$, $\mathrm{Hg}, \mathrm{Pb}$, and $\mathrm{Bi}$ concentrations are elevated in both the metropolitan area and adjacent inner bay. Figure $12 \mathrm{~b}$ shows that the spatial distribution of $\mathrm{Cd}$ in the southeast part of the Honshu Island where the Tokyo metropolitan area exists. The high concentrations of chalcophile elements such as $\mathrm{Zn}$ and $\mathrm{Cd}$ are found in both the terrestrial area and inner bay. Their spatial distribution patterns suggest that the contaminated materials remain in the bay without extending to the outer sea. This is because of the distribution of sandy sediments, 
which have a low content of heavy metals, around the entrance of the bay. Another possible explanation is the influence of water circulation in the bay. A strong bottom current (estuarine circulation) might prevent fine particles with heavy metals from reaching the outer sea because it flows from the outer sea to the bay.

\section{Vertically varying element transport}

In deep water (over 1,000 m), $\mathrm{Mn}(\mathrm{MnO}), \mathrm{Cu}, \mathrm{Zn}, \mathrm{Mo}, \mathrm{Cd}, \mathrm{Sn}, \mathrm{Sb}, \mathrm{Pb}, \mathrm{Hg}$, and $\mathrm{Bi}$ are particularly concentrated. The presence of high concentration areas of these elements found far from the adjacent terrestrial area are not explained only by materials from rivers, gravity flows, volcanic materials, metalliferous deposits, and anthropogenic acidities. For example, Figure 13 shows the geochemical maps of $\mathrm{Mn}(\mathrm{MnO})$ and $\mathrm{Cu}$ in the central part of Japan. Both elements are highly enriched in deep water, but the spatial distributions differ from one another. The enrichments of these elements in surface marine sediments are caused by early diagenetic processes, the supply of organic remains, and reductive-oxidative conditions.
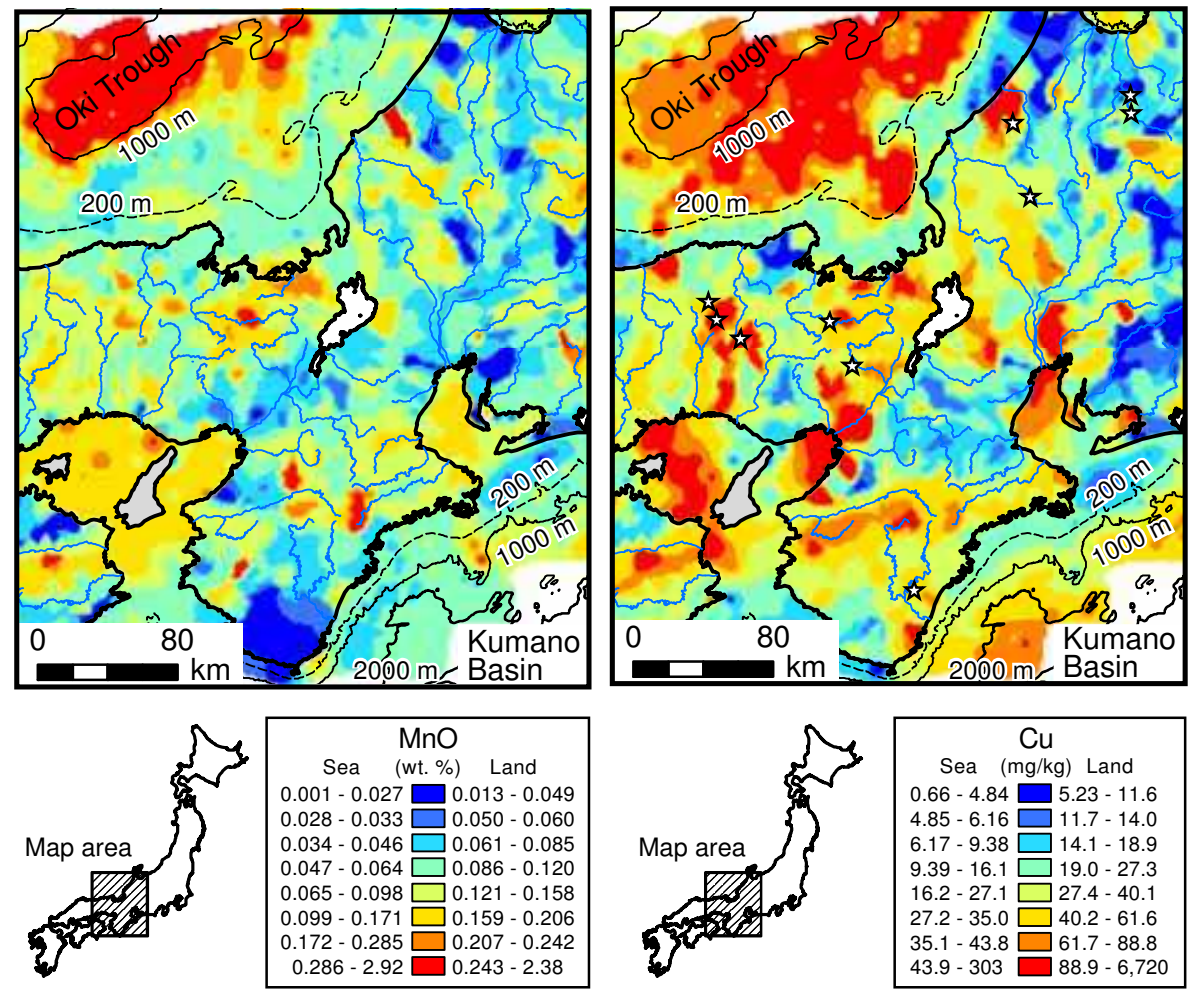

Fig. 13. Geochemical maps of $\mathrm{Mn}(\mathrm{MnO})$ and $\mathrm{Cu}$ in the central part of Japan

$\mathrm{Mn}(\mathrm{MnO}), \mathrm{Cu}, \mathrm{Mo}, \mathrm{Sb}, \mathrm{Pb}$, and $\mathrm{Bi}$ are dissolved at greater depths in sediments under reducing conditions. They diffuse upward and precipitate with $\mathrm{Mn}$ oxides or on the sediment surface under oxic conditions. This enrichment is caused by early diagenetic 
processes (e.g., Macdonald et al., 1991; Shaw et al., 1990). These processes are found in pelagic areas where the sedimentation rate is very slow. The organic remains are also an important source of elements in deep seas. $\mathrm{Cu}, \mathrm{Zn}, \mathrm{Cd}, \mathrm{Mo}, \mathrm{Sn}, \mathrm{Sb}, \mathrm{Hg}, \mathrm{Pb}$, and $\mathrm{Bi}$ are removed from surface seawater by organic matter. After they sink into deep basins, they are released into porewater during the organic matter's decomposition. We assumed that these elements are ultimately precipitated as diagenetic sulfide (authigenic precipitation) or associated with residual organic matter in marine environments (Chaillou et al., 2008; Rosenthal et al., 1995; Zheng et al., 2000). $\mathrm{Mn}(\mathrm{MnO}), \mathrm{Cu}, \mathrm{Mo}, \mathrm{Sb}, \mathrm{Pb}$, and $\mathrm{Bi}$ are dissolved in anoxic conditions and are immobile in oxic conditions, but the geochemistries of $\mathrm{Cd}$ and $\mathrm{U}$ are opposite to these elements during the early diagenetic process (Rosenthal et al., 1995). $\mathrm{Hg}$ is released from surface sediments to seawater during decomposition of organic matters (Bothner et al., 1980; Mason et al., 1994). Thus, various controlling factors affect the elemental concentrations of surface sediments in deep seas.

Figure 13 shows that $\mathrm{Mn}(\mathrm{MnO}), \mathrm{Cu}, \mathrm{Mo}, \mathrm{Sb}, \mathrm{Pb}$, and $\mathrm{Bi}$ are particularly concentrated in fine sediments of the Oki Trough below 1,000 m. The ocean floor in the deep sea (the Japan Sea Proper Water) is covered by a thick layer of cold and oxygen-rich water, and the surface sediments are under oxidative conditions (Katayama et al., 1993). Their enrichments are possibly caused by early diagenetic processes. In contrast, high $\mathrm{Cu}, \mathrm{Cd}, \mathrm{Hg}$, and $\mathrm{U}$ concentrations and the low concentration of $\mathrm{Mn}(\mathrm{MnO})$ are found in fine sediments of the Kumano Basin $(<2,000 \mathrm{~m})$. It is possible that the input of a large amount of organic matter engenders reductive conditions in surface sediments and causes high $\mathrm{Cu}, \mathrm{Cd}, \mathrm{Hg}$, and $\mathrm{U}$ concentrations. Thus, the enrichment of elements differs among deep basins.

Although $\mathrm{Mn}(\mathrm{MnO})$ enrichment occurs in the Oki Trough, the spatial distribution of high $\mathrm{Cu}$ concentrations is present even in the marginal terrace $(200-1,000 \mathrm{~m})$. Its distribution corresponds to distribution of silty and clayey sediments. The spatial distribution of $\mathrm{Cr}, \mathrm{Ni}$, $\mathrm{Zn}, \mathrm{Cd}, \mathrm{Sn}, \mathrm{Sb}, \mathrm{Pb}, \mathrm{Hg}, \mathrm{Bi}$, and $\mathrm{U}$ are also similar to that of $\mathrm{Cu}$. These results are consistent with the result that $\mathrm{Cu}$ concentration increases with decreasing particle size (Fig. 5). Ikehara (1991) suggests that muddy sediments deposit around current rips and between surface water and deep water in the Japan Sea. The results suggest that muddy sediments deposit under $200 \mathrm{~m}$, where the boundary of water mass is located between the surface water (the Tsushima Current) and deep water (the Japan Sea Proper Water). The organic remains might cause the enrichments of $\mathrm{Cr}, \mathrm{Ni}, \mathrm{Cu}, \mathrm{Zn}, \mathrm{Cd}, \mathrm{Sn}, \mathrm{Sb}, \mathrm{Pb}, \mathrm{Hg}, \mathrm{Bi}$, and $\mathrm{U}$ in the marginal terrace. In the Japan sea, however, the sedimentation process of silty and clayey particles at the boundary of water mass predominantly determine the spatial distribution of $\mathrm{Cr}, \mathrm{Ni}, \mathrm{Cu}$, $\mathrm{Zn}, \mathrm{Cd}, \mathrm{Sn}, \mathrm{Sb}, \mathrm{Pb}, \mathrm{Hg}, \mathrm{Bi}$, and $\mathrm{U}$ concentrations. Early diagenetic processes influence the enrichments of $\mathrm{Mn}(\mathrm{MnO}), \mathrm{Cu}, \mathrm{Mo}, \mathrm{Sb}, \mathrm{Pb}$, and $\mathrm{Bi}$ in water at a depth of $>1,000 \mathrm{~m}$.

\section{Conclusion}

The spatial distribution patterns of the elemental concentrations found in geochemical maps in coastal seas floor along with terrestrial areas are useful to define the natural geochemical background variation, mass transport, and contamination processes. We intend to elucidate geochemical differences between terrestrial surface sediments and coastal and open sea sediments comprehensively. The elemental abundance patterns of coastal sea sediments are consistent with those of stream sediments and the Japanese upper crust materials. This fact suggests that coastal sea sediments are originally adjacent terrestrial materials. However, the 
mineralogical compositions of coastal sea sediments change with particle size, resulting in a change in the chemical compositions. Coarse sediments in the marine environment contain quartz and calcareous shells, which enhance $\mathrm{Si}, \mathrm{Ca}$, and $\mathrm{Sr}$ concentrations and deplete the other elements. Consequently, the concentrations of most elements increase with decreasing particle size. The particle size effect often conceals the horizontal mass transfer process.

Because Japan is located in the subducting zone, the Japanese marine environment has a narrow continental shelf and a steep slope from the coast. The horizontal mass movement in the sea reflects the sea topography and is followed by a gravity flow and an oceanic current. Terrestrial materials supplied through rivers initially fan out on the shore $(\sim 20 \mathrm{~km})$; subsequently, they are gradually transported off shore (over $100 \mathrm{~km}$ ) by gravity over a long period of time. An oceanic current conveys fine sediments up to a distance of 100-200 km from the coast, along the coast. Heavy metals and toxic elements such as $\mathrm{Zn}, \mathrm{Cd}$, and $\mathrm{Hg}$ are present in high concentrations in urban areas and are exposed to an adjacent inner bay. However, their high concentration area is found only in the bay: the contaminated materials remain in the bays without extending to the outer sea. These elements are also abundant in terrestrial areas having metalliferous deposits. However, the adjoining coastal seas are only enriched in Zn and $\mathrm{Pb}$. The mass transfer process of these elements from sediments associated with metalliferous deposits to sea is different from that of anthropogenic disposed elements. We can see some extensive distributions of volcanic materials in marine environment. The distribution of volcanic materials such as pyroclastic materials, pumice, and ash is indicative of mass transfer through atmosphere, although that is not the direct mass transfer from land to sea. Thus, we can see various kinds of horizontal mass transfer processes from these comprehensive geochemical maps. In contrast, the spatial distribution of $\mathrm{Cu}, \mathrm{Zn}, \mathrm{Cd}, \mathrm{Mo}, \mathrm{Sn}, \mathrm{Sb}, \mathrm{Hg}, \mathrm{Pb}, \mathrm{Bi}$, and $\mathrm{U}$ in the deep-sea basins is determined by early diagenetic processes in sediments, oxidation-reduction potentials in surface sediments, and the input of organic remains from surface water. These processes represent vertical element transport processes. The enrichments of these elements are not continuous between land and sea. That is, the vertical element transport process conceals the horizontal mass transfer process.

\section{Acknowledgements}

The authors express their special appreciation to Ken Ikehara, Takeshi Nakajima, Hajime Katayama, and Atsushi Noda for offering marine sediment samples stored in a sample chamber and collecting new samples; Shigeru Terashima and Yoshiko Tachibana for their technical assistance in preparing samples and analyzing elemental concentrations of stream and coastal sea sediment samples; and Daisaku Kawabata for assisting in GIS analyses. We are also grateful to Takumi Tsujino, Masumi Ujiie-Mikoshiba, and Takashi Okai for their useful suggestions, which helped to improve an earlier version of the manuscript. The authors are grateful to the Japan Oceanographic Data Centre (JODC) for offering data files.

\section{References}

Balls, P.W., Hull, S., Miller, B.S., Pirie, J.M. \& Proctor, W. (1997) Trace metal in Scottish estuarine and coastal sediments. Marine Pollution Bulletin, 34(1), 42-50, ISSN: 0025326X. 
Bølviken, B., Bergstrøm, J., Bjørklund, A., Kontio, M., Lehmuspelto, P., Lindholm, T., Magnusson, J., Ottesen, R.T., Steenfelt, A. \& Volden, T. (1986) Geochemical Atlas of Northern Fennoscandia. Geological Surveys of Finland, Norway and Sweden, ISBN: 91-7158-383-1, Helsinki, Trondheim and Stockholm.

Bothner, M.H., Jahnke, R.A., Peterson, M.L. \& Carpenter, R. (1980) Rate of mercury loss from contaminated estuarine sediments. Geochimica et Cosmochimica Acta, 44(2), 273-285, ISSN: 0016-7037.

Chaillou, G., Schäfer, J., Blanc, G. \& Anschutz, P. (2008) Mobility of Mo, U, As, and Sb within modern turbidites. Marine Geology, 254(3-4), 171-179, ISSN: 00253227.

Darnley, A.G., Björklund, A., Bølviken, B., Gustavsson, N., Koval, P.V., Plant, J.A., Steenfelt, A., Tauchid, M., Xie, X., Garrett, R.G. \& Hall, G.E.M. (1995) A global geochemical database for environmental and resource management: recommendations for international geochemical mapping. Science Report 19. UNESCO Publishing, ISBN: 92-3-103085-X, Paris.

Degens, E., Kempe, S. \& Richey, J. (1991) Biogeochemistry of major world rivers. John Wiley \& Sons, ISBN: 0-471-92676-0, Chichester.

Fauth, H., Hindel, R., Siewers, U. \& Zinner, J. (1985) Geochemischer Atlas Bundesrepublik Deutschland. Bundesanstatt für Geowissenschaften and Rohstoffe (BGR), ISBN: 39801097-0-4, Hannover.

Fukuoka, T. (1991) Identification of particular tephras by trace element compositions of volcanic glass. The Earth Montly, 13(3), 186-192, ISSN: 0387-3498 (in Japanese).

Geological Survey of Japan (1992). Geological Map of elpan 1:1,000,000, third ed. Geological Survey of Japan, Tsukuba.

Gustavsson, N., BøLviken, B., Smith, D.B. \& Severson, R.C. (2001) Geochemical landscapes of the conterminous United States: New map presentations for 22 elements. US Geological Survey professional paper, 1648, 1-38, ISSN: 1044-9612.

Howarth, R.J. \& Thornton, I. (1983) Regional Geochemical Mapping and its Application to Environmental Studies. In Applied Environmental Geochemistry, Thornton, I. (Ed.) p. 41-73. Academic Press, ISBN: 0-12-690640-8, London.

Hudson-Edwards, K.A., Macklin, M.G., Curtis, C.D. \& Vaughan, D.J. (1996) Processes of formation and distribution of $\mathrm{Pb}-, \mathrm{Zn}-, \mathrm{Cd}-$, and $\mathrm{Cu}$-bearing minerals in the Tyne Basin, northeast England: Implications for metal-contaminated river systems. Environmental Science \& Technology, 30(1), 72-80, ISSN: 0013-936X.

Ibbeken, H. \& Schleyer, R. (1991) Source and sediment: a case study of provenance and mass balance at an active plate margin (Calabria, Southern Italy). Springer-Verlag, ISBN: 0387-53282-X, Berlin.

Ikehara, K. (1988). Sedimentological Map of Tosa Wan. 1:200,000 Marine Geology Map Series 34.

Ikehara, K. (1991). Modern sedimentation off San'in district in the southern Japan Sea. In: Oceanography of Asian Marginal Seas, Takano, K. (Ed.), 143-161, Elsevier, ISBN: 0444-88805-5, Amsterdam.

Imai, N. (1987) Multielement analysis of stream sediment by ICP-AES. Bunseki Kagaku, 36(4), T41-T45, ISSN: 0525-1931 (in Japanese). 
Imai, N. (1990) Multielement analysis of rocks with the use of geological certified reference material by inductively coupled plasma mass spectrometry. Analytical Sciences, 6(3), 389-395, ISSN: 0910-6340.

Imai, N., Terashima, S., Itoh, S. \& Ando, A. (1995) 1994 compilation of analytical data for minor and trace-elements in 17 GSJ geochemical reference samples, igneous rock series. Geostandards Newsletter, 19(2), 135-213, ISSN: 0150-5505.

Imai, N., Terashima, S., Katayama, H., Nakajima, T., Ikehara, K. \& Taniguchi, M. (1997) Geochemical behavior of heavy metals in coastal marine sediments from the eastern margin of the Japan Sea. Bulletin of the Geological Survey of clopan, 48(9), 511530, ISSN: 0016-7665 (in Japanese, with English abstr.).

Imai, N., Terashima, S., Ohta, A., Mikoshiba, M., Okai, T., Tachibana, Y., Togashi, S., Matsuhisa, Y., Kanai, Y. , Kamioka, H. \& Taniguchi, M. (2004) Geochemical map of etapan. Geological Survey of Japan, AIST (in Japanese, with English abstr.).

Imai, N., Terashima, S., Ohta, A., Mikoshiba, M., Okai, T., Tachibana, Y., Ikehara, K., Katayama, H., Noda, A., Togashi, S., Matsuhisa, Y., Kanai, Y. \& Kamioka, H. (2010) Elemental distribution in Japan -Geochemical map of Japan- (in Japanese, with English abstract). Geological Survey of Japan, AIST, Tsukuba. Database of elemental distribution in Japan <http://riodb02.ibase.aist.go.jp/geochemmap/>.

Inouchi, Y., Ohtsuka, M., Kumon, F., Motoyama, I. \& Katayama, H. (1995) Surface sediment characteristics around Ishikari Bay. In: Comprehensive Study on Environmental Changes in the Southwestern Hokkaido Area, Okamura, Y. \& Inouchi Y. (Eds.), 63-88, Geological Survey of Japan (in Japanese).

Irion, G., Müller, J., de Mello, J.N. \& Junk, W.J. (1995) Quaternary geology of the Amazonian lowland. Geo-Marine Letters, 15(3-4), 172-178, ISSN: 0276-0460.

Karageorgis, A.P., Anagnostou, C.L. \& Kaberi, H. (2005) Geochemistry and mineralogy of the NW Aegean Sea surface sediments: implications for river runoff and anthropogenic impact. Applied Geochemistry, 20(1), 69-88, ISSN: 0883-2927.

Katayama, H. (2008). Sedimentological Map of Ishikari Bay. 1:200,000 Marine Geology Map Series 66 (CD-ROM version).

Katayama, H., Sato, M. \& Ikehara, K. (1993). Sedimentological Map offshore of Kyo-ga Misaki. 1:200,000 Marine Geology Map Series 38.

Kikkawa, K., Imai, N., Okumura, K. \& Mizuno, K. (1989). Identification of tephra layers by chemical analysis of volcanic glass using inductively coupled plasma emission spectrometry (ICP). Bulletin of the Geological Survey of ctapan, 40(1), 1-18, ISSN: 00167665 (in Japanese, with English abstr.).

Kuroda, H., Isoda, Y., Takeoka, H. \& Honda, S. (2006) Coastal current on the eastern shelf of Hidaka Bay. eburnal of Oceanography, 62(5), 731-744, ISSN: 0916-8370.

Lis, J. \& Pasieczna, A. (1995) Geochemical atlas of Poland 1: 2500000. Polish Geological Institute, ISBN: 83-903705-9-X, Warszawa.

Macdonald, R.W., Macdonald, D.M., O'Brien, M.C. \& Gobeil, C. (1991) Accumulation of heavy-metals $(\mathrm{Pb}, \mathrm{Zn}, \mathrm{Cu}, \mathrm{Cd})$, carbon and nitrogen in sediments from strait of Georgia, B.C., Canada. Marine Chemistry, 34(1-2), 109-135, ISSN: 03044203 . 
Machida, H. (1999) The stratigraphy, chronology and distribution of distal marker-tephras in and around Japan. Global and Planetary Change, 21(1-3), 71-94, ISSN: 0921-8181.

Mason, R.P., Fitzgerald, W.F. \& Morel, F.M.M. (1994) The biogeochemical cycling of elemental mercury: Anthropogenic influences. Geochimica et Cosmochimica Acta, 58(15), 3191-3198, ISBN: 0016-7037.

Noda, A., Katayama, H., Arai, K. \& Furukawa, R. (2007). Surface sediment characteristics off Hidaka region. In: Cruise Report: Marine geological and Geophysical Studies. On the Collision Zone of Kurile and Northeast elopan Arcs - off Hidaka Area -, Katayama, H. (Ed.), 76-96. Geological Survey of Japan, AIST 39 (in Japanese).

Ohta, A., Imai, N., Okai, T., Endo, H., Kawanabe, S., Ishii, T., Taguchi, Y. \& Kamioka, H. (2002) The characteristics of chemical distribution patterns in and around Yamagata city -Geochemical map in the southern area of Yamagata Basin-. Chikyukagaku (Geochemistry), 36(3), 109-125, ISSN: 0386-4073 (in Japanese, with English abstr.).

Ohta, A., Imai, N., Terashima, S. \& Tachibana, Y. (2004a) Investigation of elemental behaviors in Chugoku region of Japan based on geochemical map utilizing stream sediments. Chikyukagaku (Geochemistry), 38(4), 203-222, ISSN: 0386-4073 (in Japanese, with English abstr.).

Ohta, A., Imai, N., Terashima, S., Tachibana, Y., Ikehara, K. \& Nakajima, T. (2004b) Geochemical mapping in Hokuriku, Japan: influence of surface geology, mineral occurrences and mass movement from terrestrial to marine environments. Applied Geochemistry, 19(9), 1453-1469, ISSN: 0883-2927.

Ohta, A., Imai, N., Terashima, S. \& Tachibana, Y. (2005a) Influence of surface geology and mineral deposits on the spatial distributions of elemental concentrations in the stream sediments of Hokkaido, Japan. eburnal of Geochemical Exploration, 86(2), 86103, ISSN: 0375-6742.

Ohta, A., Imai, N., Terashima, S. \& Tachibana, Y. (2005b) Application of multi-element statistical analysis for regional geochemical mapping in Central Japan. Applied Geochemistry, 20(5), 1017-1037, ISSN: 0883-2927.

Ohta, A., Imai, N., Terashima, S., Tachibana, Y., Ikehara, K., Okai, T., Ujiie-Mikoshiba, M. \& Kubota, R. (2007) Elemental distribution of coastal sea and stream sediments in the island-arc region of Japan and mass transfer processes from terrestrial to marine environments. Applied Geochemistry, 22(12), 2872-2891, ISSN: 0883-2927.

Ohta, A., Imai, N., Terashima, S., Tachibana, Y., Ikehara, K., Katayama, H. \& Noda, A. (2010) Factors controlling regional spatial distribution of 53 elements in coastal sea sediments in northern Japan: Comparison of geochemical data derived from stream and marine sediments. Applied Geochemistry, 25(3), 357-376, ISSN: 08832927.

Reimann, C., Äyräs, M., Chekushin, V., Bogatyrev, I., Boyd, R., Caritat, P.d., Dutter, R., Finne, T.E., Halleraker, J.H., Jæger, Ø., Kashulina, G., Lehto, O., Niskavaara, H., Pavlov, V., Räisänen, M.L., Strand, T. \& Volden, T. (1998) Environmental Geochemical Atlas of the Central Barents Region. Geological Survey of Norway, ISBN: 82-7385-1761, Trondheim. 
Reimann, C. (2005) Geochemical mapping: technique or art? Geochemistry: Exploration, Environment, Analysis, 5(4), 359-370, ISSN: 1467-7873.

Rosenthal, Y., Lam, P., Boyle, E.A. \& Thomson, J. (1995) Authigenic cadmium enrichments in suboxic sediments: Precipitation and postdepositional mobility. Earth and Planetary Science Letters, 132(1-4), 99-111, ISSN: 0012-821X.

Salminen, R., Batista, M.J., Bidovec, M., Demetriades, A., B., D.V., De Vos, W., Duris, M., Gilucis, A., Gregorauskiene, V., Halamic, J., Heitzmann, P., Lima, A., Jordan, G., Klaver, G., Klein, P., Lis, J., Locutura, J., Marsina, K., Mazreku, A., O'Connor, P.J., Olsson, S.Å., Ottesen, R.-T., Petersell, V., Plant, J.A., Reeder, S., Salpeteur, I., Sandström, H., Siewers, U., Steenfelt, A. \& Tarvainen, T. (2005) Geochemical atlas of Europe. Part 1 - Background Information, Methodology and Maps. Geological Survey of Finland, ISBN: 951-690-921-3, Espoo.

Shacklette, H.T. \& Boerngen, J.G. (1984) Element concentrations in soils and other surficial materials of the conterminous United States. USGS Geological Survey Professional paper. United States Government Printing Office, ISSN: 0096-0446.

Shaw, T.J., Gieskes, J.M. \& Jahnke, R.A. (1990) Early diagenesis in differing depositional environments: The response of transition metals in pore water. Geochimica et Cosmochimica Acta, 54(5), 1233-1246, ISSN: 0016-7037.

Taylor, S.R. \& McLennan, S.M. (1995) The geochemical evolution of the continental crust. Reviews of Geophysics, 33(2), 241-265, ISSN: 8755-1209.

Thalmann, F., Schermann, O., Schroll, E. \& Hausberger, G. (1988) Geochemical Atlas of the Republic of Austria 1:1,000,000. Geological Survey of Austria.

Togashi, S., Imai, N., Okuyama-Kusunose, Y., Tanaka, T., Okai, T., Koma, T. \& Murata, Y. (2000) Young Upper Crustal Chemical Composition of the Orogenic Japan Arc. Geochemistry Geophysics Geosystems, 1(11), 2000GC000083, ISSN: 15252027.

Ujiie-Mikoshiba, M., Imai, N., Terashima, S., Tachibana, Y. \& Okai, T. (2006) Geochemical mapping in northern Honshu, Japan. Applied Geochemistry, 21(3), 492-514, ISSN: 0883-2927.

Voutsinou-Taliadouri, F. \& Varnavas, S.P. (1995) Geochemical and Sedimentological Patterns in the Thermaikos Gulf, North-West Aegean Sea, Formed from a Multisource of Elements. Estuarine Coastal and Shelf Science, 40(3), 295-320, ISSN: $0272-7714$.

Wang, S.S., Cao, Z.M., Lan, D.Z., Zheng, Z.C. \& Li, G.H. (2008) Concentration distribution and assessment of several heavy metals in sediments of west-four Pearl River Estuary. Environmental Geology, 55(5), 963-975, ISSN: 0943-0105.

Watson, D.F. \& Philip, G.M. (1985) A refinement of inverse distance weighted interpolation. Geo-Processing, 2(4), 315-327, ISSN: 0165-2273.

Weaver, T.A., Broxton, D.E., Bolivar, S.L. \& Freeman, S.H. (1983) The Geochemical Atlas of Alaska: Compiled by the Geochemistry Group, Earth Sciences Division, Los Alamos National Laboratory. GJBX-32(83), Los Alamos.

Webb, J.S., Thornton, I., Thompson, M., Howarth, R.J. \& Lowenstein, P.L. (1978) The Wolfson Geochemical Atlas of England and Wales. Clarendon Press, ISBN: 0-19-891113-0, Oxford. 
Xie, X.J., Mu, X.Z. \& Ren, T.X. (1997) Geochemical mapping in China. eburnal of Geochemical Exploration, 60(1), 99-113, ISSN: 0375-6742.

Zheng, C. (1994). Atlas of Soil Environmental Background Value in the People's Republic of China. China Environmental Science Press, ISBN: 7800931374, Beijing.

Zheng, Y., Anderson, R.F., van Geen, A. \& Kuwabara, J. (2000) Authigenic molybdenum formation in marine sediments: A link to pore water sulfide in the Santa Barbara Basin. Geochimica et Cosmochimica Acta, 64(24), 4165-4178, ISSN: 00167037. 


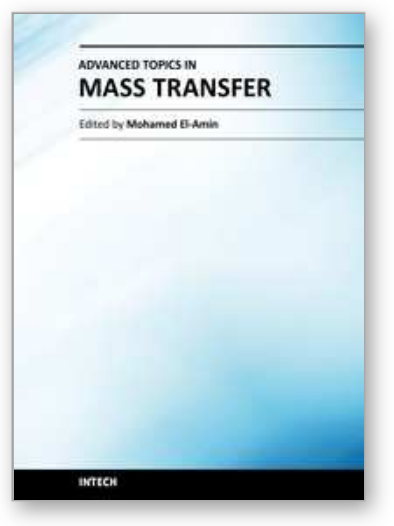

\author{
Advanced Topics in Mass Transfer \\ Edited by Prof. Mohamed El-Amin
}

ISBN 978-953-307-333-0

Hard cover, 626 pages

Publisher InTech

Published online 21, February, 2011

Published in print edition February, 2011

This book introduces a number of selected advanced topics in mass transfer phenomenon and covers its theoretical, numerical, modeling and experimental aspects. The 26 chapters of this book are divided into five parts. The first is devoted to the study of some problems of mass transfer in microchannels, turbulence, waves and plasma, while chapters regarding mass transfer with hydro-, magnetohydro- and electro- dynamics are collected in the second part. The third part deals with mass transfer in food, such as rice, cheese, fruits and vegetables, and the fourth focuses on mass transfer in some large-scale applications such as geomorphologic studies. The last part introduces several issues of combined heat and mass transfer phenomena. The book can be considered as a rich reference for researchers and engineers working in the field of mass transfer and its related topics.

\title{
How to reference
}

In order to correctly reference this scholarly work, feel free to copy and paste the following:

Atsuyuki Ohta and Noboru Imai (2011). Comprehensive Survey of Multi-Elements in Coastal Sea and Stream Sediments in the Island Arc Region of Japan: Mass Transfer from Terrestrial to Marine Environments, Advanced Topics in Mass Transfer, Prof. Mohamed El-Amin (Ed.), ISBN: 978-953-307-333-0, InTech, Available from: http://www.intechopen.com/books/advanced-topics-in-mass-transfer/comprehensive-survey-ofmulti-elements-in-coastal-sea-and-stream-sediments-in-the-island-arc-region-

\section{INTECH}

open science | open minds

\author{
InTech Europe \\ University Campus STeP Ri \\ Slavka Krautzeka 83/A \\ 51000 Rijeka, Croatia \\ Phone: +385 (51) 770447 \\ Fax: +385 (51) 686166 \\ www.intechopen.com
}

\author{
InTech China \\ Unit 405, Office Block, Hotel Equatorial Shanghai \\ No.65, Yan An Road (West), Shanghai, 200040, China \\ 中国上海市延安西路65号上海国际贵都大饭店办公楼 405 单元 \\ Phone: +86-21-62489820 \\ Fax: $+86-21-62489821$
}


(C) 2011 The Author(s). Licensee IntechOpen. This chapter is distributed under the terms of the Creative Commons Attribution-NonCommercialShareAlike-3.0 License, which permits use, distribution and reproduction for non-commercial purposes, provided the original is properly cited and derivative works building on this content are distributed under the same license. 